\title{
LEVEL II SCOUR ANALYSIS FOR BRIDGE 50 (STARTH00250050) on TOWN HIGHWAY 25, crossing LEWIS CREEK, STARKSBORO, VERMONT
}

Open-File Report 97-798

Prepared in cooperation with

VERMONT AGENCY OF TRANSPORTATION

and

FEDERAL HIGHWAY ADMINISTRATION

U.S. Department of the Interior

U.S. Geological Survey

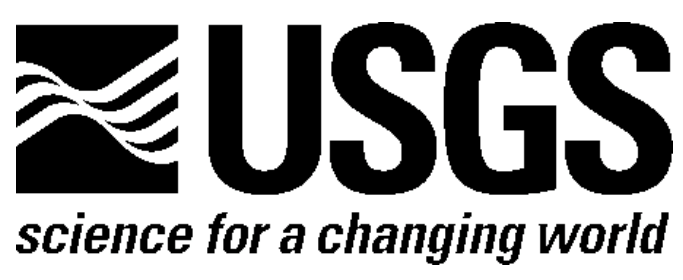




\section{LEVEL II SCOUR ANALYSIS FOR BRIDGE 50 (STARTH00250050) on TOWN HIGHWAY 25, crossing LEWIS CREEK, STARKSBORO, VERMONT}

By RONDA L. BURNS and ERICK M. BOEHMLER

U.S. Geological Survey Open-File Report 97-798

Prepared in cooperation with

VERMONT AGENCY OF TRANSPORTATION and

FEDERAL HIGHWAY ADMINISTRATION 


\title{
U.S. DEPARTMENT OF THE INTERIOR BRUCE BABBITT, Secretary
}

\author{
U.S. GEOLOGICAL SURVEY \\ Mark Shaefer, Acting Director
}

For additional information write to:

District Chief

U.S. Geological Survey 361 Commerce Way

Pembroke, NH 03275-3718
Copies of this report may be purchased from:

U.S. Geological Survey

Branch of Information Services

Open-File Reports Unit

Box 25286

Denver, CO 80225-0286 


\section{CONTENTS}

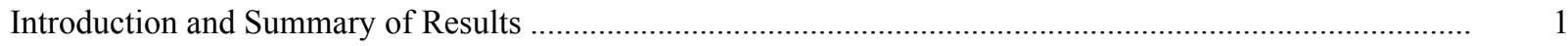

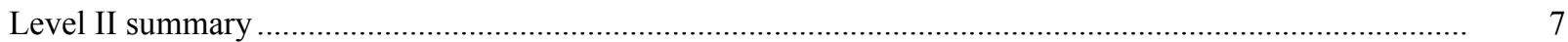

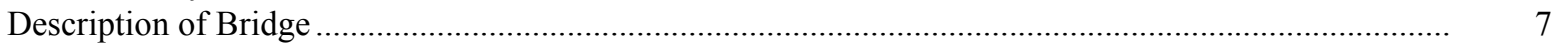

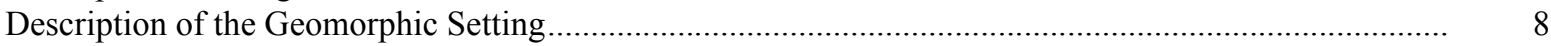

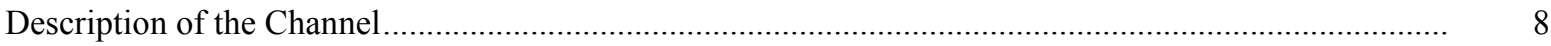

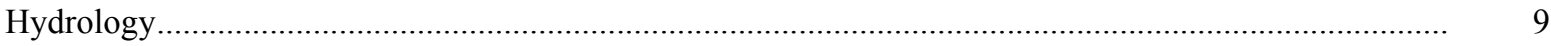

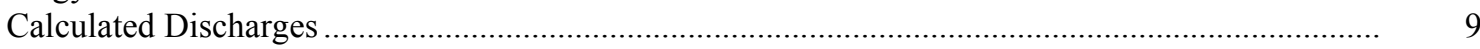

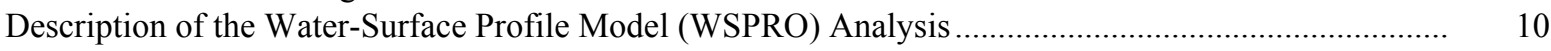

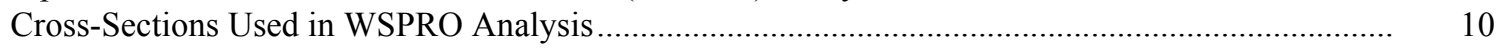

Data and Assumptions Used in WSPRO Model ...................................................................... 11

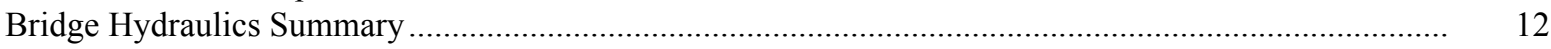

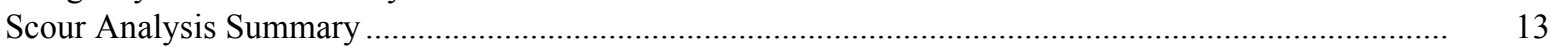

Special Conditions or Assumptions Made in Scour Analysis ...................................................... 13

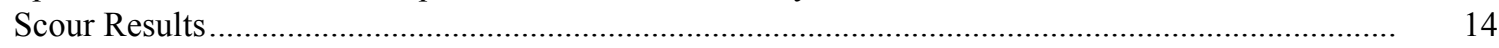

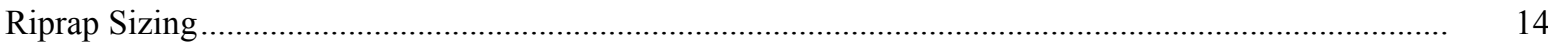

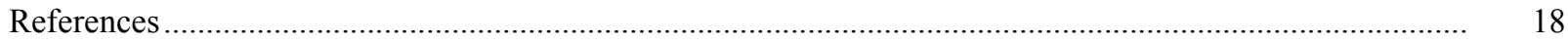

Appendixes:

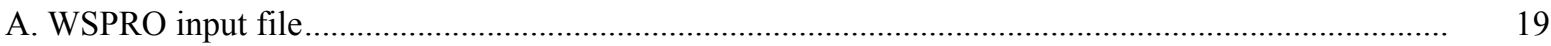

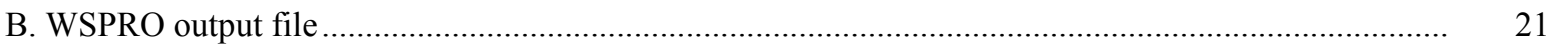

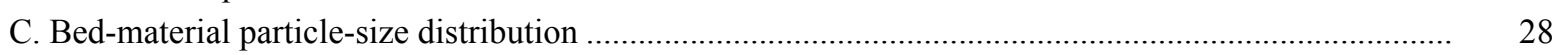

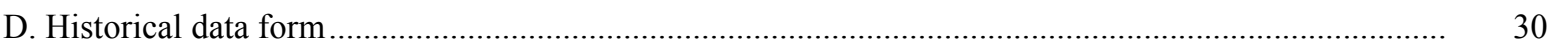

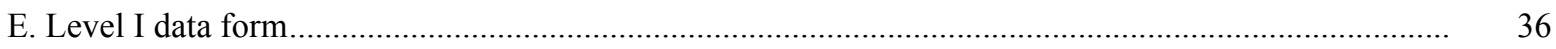

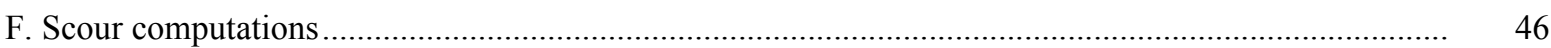

\section{FIGURES}

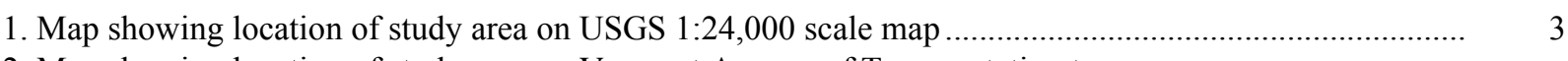

2. Map showing location of study area on Vermont Agency of Transportation town
highway map

3. Structure STARTH00250050 viewed from upstream (June 12, 1996) …................................................ 5

4. Downstream channel viewed from structure STARTH00250050 (June 12, 1996)................................ 5

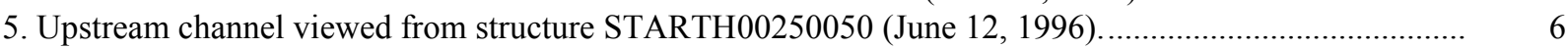

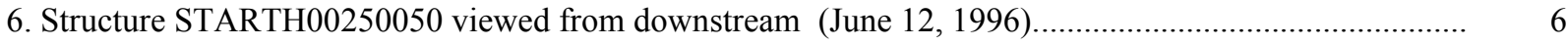

7. Water-surface profiles for the 100- and 500-year discharges at structure

STARTH00250050 on Town Highway 25, crossing Lewis Creek,

Starksboro, Vermont.

8. Scour elevations for the 100- and 500-year discharges at structure

STARTH00250050 on Town Highway 25, crossing Lewis Creek,

Starksboro, Vermont.

\section{TABLES}

1. Remaining footing/pile depth at abutments for the 100-year discharge at structure

STARTH00250050 on Town Highway 25, crossing Lewis Creek,

Starksboro, Vermont

2. Remaining footing/pile depth at abutments for the 500-year discharge at structure

STARTH00250050 on Town Highway 25, crossing Lewis Creek,

Starksboro, Vermont 


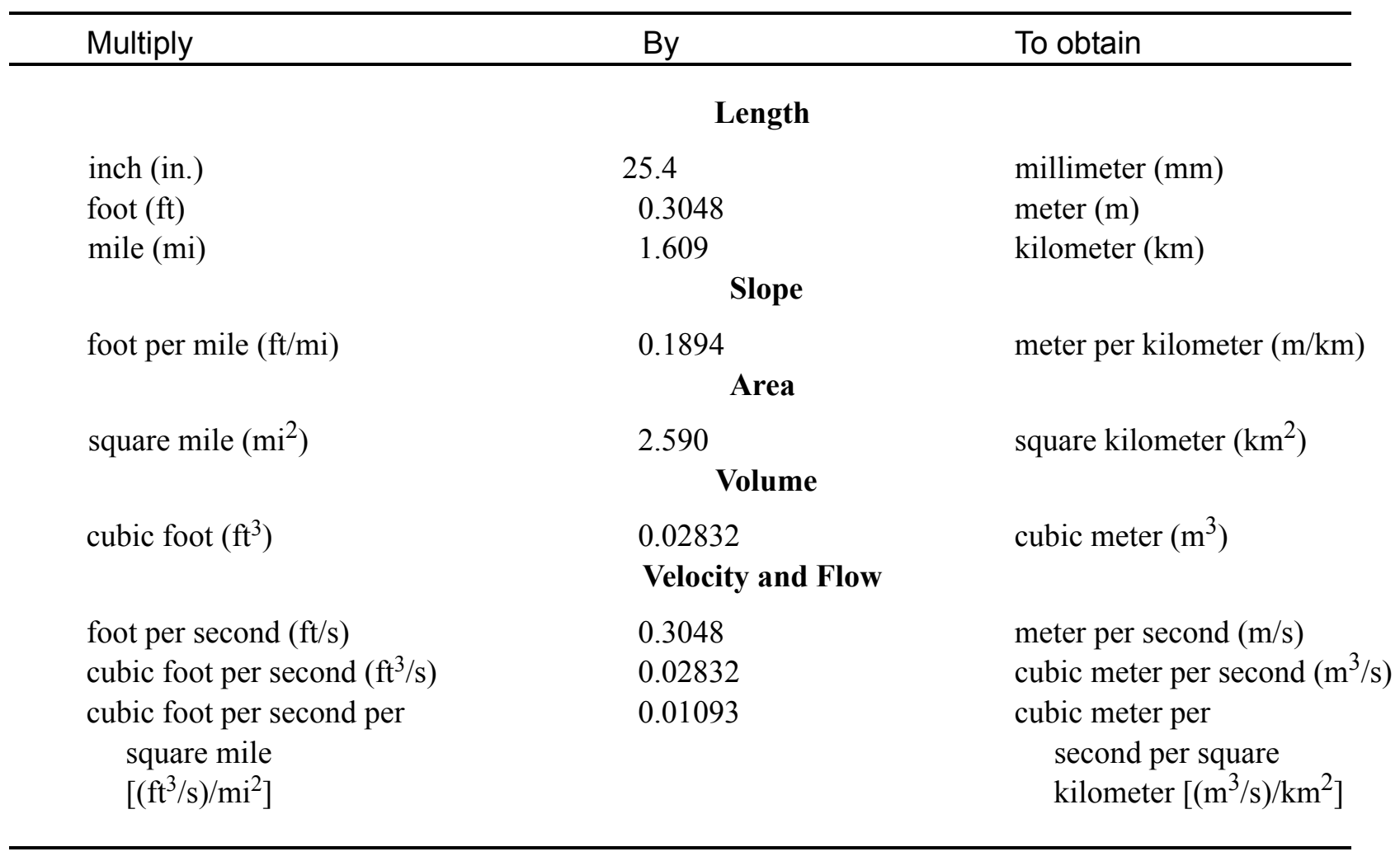

\section{OTHER ABBREVIATIONS}

$\begin{array}{lrlr}\mathrm{BF} & \text { bank full } & \text { LWW } & \text { left wingwall } \\ \mathrm{cfs} & \text { cubic feet per second } & \text { MC } & \text { main channel } \\ \mathrm{D}_{50} & \text { median diameter of bed material } & \text { RAB } & \text { right abutment } \\ \mathrm{DS} & \text { downstream } & \text { RABUT } & \text { face of right abutment } \\ \mathrm{elev} & \text { elevation } & \text { RB } & \text { right bank } \\ \mathrm{f} / \mathrm{p} & \text { flood plain } & \text { ROB } & \text { right overbank } \\ \mathrm{ft}^{2} & \text { square feet } & \text { RWW } & \text { right wingwall } \\ \mathrm{ft} / \mathrm{ft} & \text { feet per foot } & \text { TH } & \text { town highway } \\ \mathrm{JCT} & \text { junction } & \text { UB } & \text { under bridge } \\ \mathrm{LAB} & \text { left abutment } & \text { US } & \text { upstream } \\ \mathrm{LABUT} & \text { face of left abutment } & \text { USGS } & \text { United States Geological Survey } \\ \mathrm{LB} & \text { left bank } & \text { VTAOT Vermont Agency of Transportation } \\ \mathrm{LOB} & \text { left overbank } & \text { WSPRO } & \text { water-surface profile model }\end{array}$

In this report, the words "right" and "left" refer to directions that would be reported by an observer facing downstream. Sea level: In this report, "sea level" refers to the National Geodetic Vertical Datum of 1929-- a geodetic datum derived from a general adjustment of the first-order level nets of the United States and Canada, formerly called Sea Level Datum of 1929.

In the appendices, the above abbreviations may be combined. For example, USLB would represent upstream left bank. 


\title{
LEVEL II SCOUR ANALYSIS FOR BRIDGE 50 (STARTH00250050) ON TOWN HIGHWAY 25, CROSSING LEWIS CREEK, STARKSBORO, VERMONT
}

\author{
By Ronda L. Burns and Erick M. Boehmler
}

\section{INTRODUCTION AND SUMMARY OF RESULTS}

This report provides the results of a detailed Level II analysis of scour potential at structure STARTH00250050 on Town Highway 25 crossing Lewis Creek, Starksboro, Vermont (figures 1-8). A Level II study is a basic engineering analysis of the site, including a quantitative analysis of stream stability and scour (U.S. Department of Transportation, 1993). Results of a Level I scour investigation also are included in Appendix E of this report. A Level I investigation provides a qualitative geomorphic characterization of the study site. Information on the bridge, gleaned from Vermont Agency of Transportation (VTAOT) files, was compiled prior to conducting Level I and Level II analyses and is found in Appendix D.

The site is in the Green Mountain section of the New England physiographic province in west-central Vermont. The $10.9-\mathrm{mi}^{2}$ drainage area is in a predominantly rural and forested basin. In the vicinity of the study site, the surface cover is pasture on the left bank downstream and upstream of the bridge. On the right bank upstream and downstream of the bridge the surface cover is forest.

In the study area, Lewis Creek has an incised, straight channel with a slope of approximately $0.007 \mathrm{ft} / \mathrm{ft}$, an average channel top width of $64 \mathrm{ft}$ and an average bank height of $7 \mathrm{ft}$. The channel bed material ranges from sand to boulder with a median grain size $\left(\mathrm{D}_{50}\right)$ of $35.4 \mathrm{~mm}(0.116 \mathrm{ft})$. The geomorphic assessment at the time of the Level I and Level II site visit on June 12, 1996, indicated that the reach was stable.

The Town Highway 25 crossing of Lewis Creek is a 28-ft-long, one-lane bridge consisting of one 25-foot steel-beam span (Vermont Agency of Transportation, written communication, December 15, 1995). The opening length of the structure parallel to the bridge face is $23.8 \mathrm{ft}$. The bridge is supported by vertical, concrete abutments with wingwalls on all corners except the downstream left. The channel is skewed approximately zero degrees to the opening and the opening-skew-to-roadway is also zero degrees. 
A scour hole $1.0 \mathrm{ft}$ deeper than the mean thalweg depth was observed along the right abutment during the Level I assessment. Also, the footing is exposed along the left and right abutments and all three wingwalls. The scour countermeasures at the site included type-1 stone fill (less than 12 inches diameter) along the left abutment and type- 2 stone fill (less than 36 inches diameter) along the right abutment and the upstream and downstream right wingwalls. Additional details describing conditions at the site are included in the Level II Summary and Appendices D and E.

Scour depths and recommended rock rip-rap sizes were computed using the general guidelines described in Hydraulic Engineering Circular 18 (Richardson and others, 1995) for the 100- and 500-year discharges. In addition, the incipient roadway-overtopping discharge was determined and analyzed as another potential worst-case scour scenario. Total scour at a highway crossing is comprised of three components: 1) long-term streambed degradation; 2) contraction scour (due to accelerated flow caused by a reduction in flow area at a bridge) and; 3 ) local scour (caused by accelerated flow around piers and abutments). Total scour is the sum of the three components. Equations are available to compute depths for contraction and local scour and a summary of the results of these computations follows.

Contraction scour for all modelled flows ranged from 5.2 to $9.1 \mathrm{ft}$. The worst-case contraction scour occurred at the 500-year discharge. Abutment scour ranged from 13.1 to $18.2 \mathrm{ft}$. The worst-case abutment scour occurred at the 500-year discharge. Additional information on scour depths and depths to armoring are included in the section titled "Scour Results". Scoured-streambed elevations, based on the calculated scour depths, are presented in tables 1 and 2. A cross-section of the scour computed at the bridge is presented in figure 8. Scour depths were calculated assuming an infinite depth of erosive material and a homogeneous particle-size distribution.

It is generally accepted that the Froehlich equation (abutment scour) gives "excessively conservative estimates of scour depths" (Richardson and others, 1995, p. 47). Usually, computed scour depths are evaluated in combination with other information including (but not limited to) historical performance during flood events, the geomorphic stability assessment, existing scour protection measures, and the results of the hydraulic analyses. Therefore, scour depths adopted by VTAOT may differ from the computed values documented herein. 


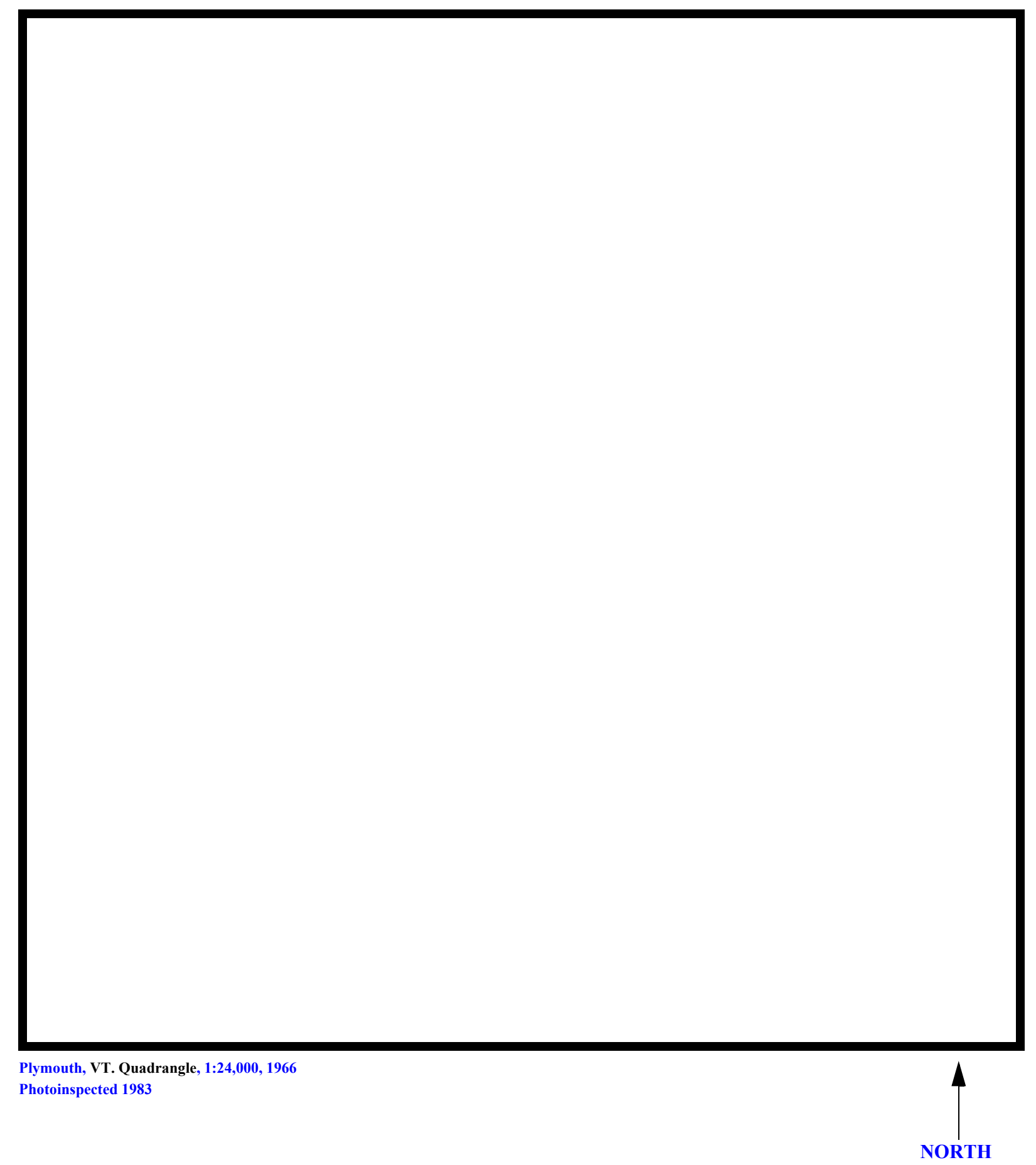

Figure 1. Location of study area on USGS 1:24,000 scale map. 
Figure 2. Location of study area on Vermont Agency of Transportation town highway map. 

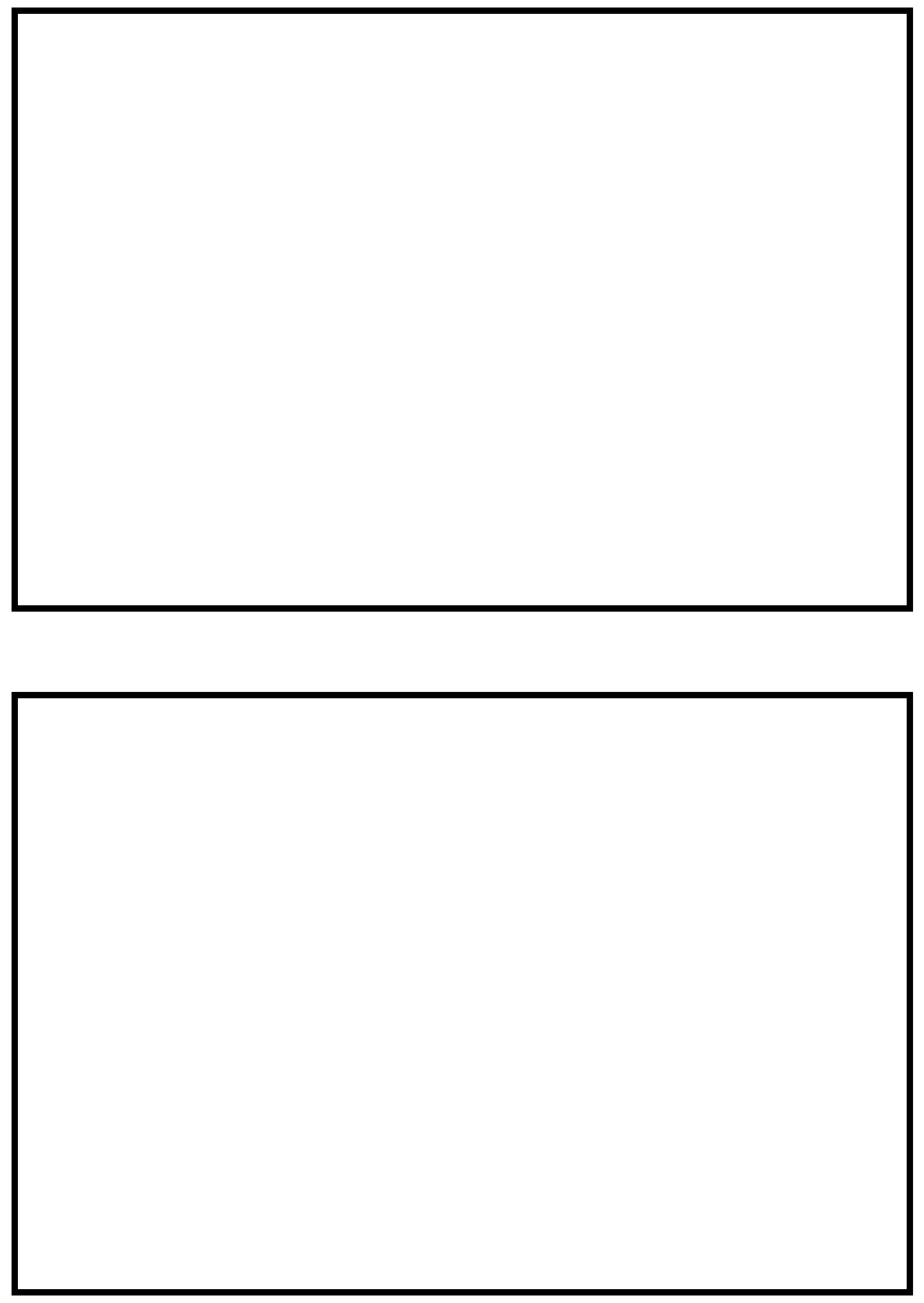

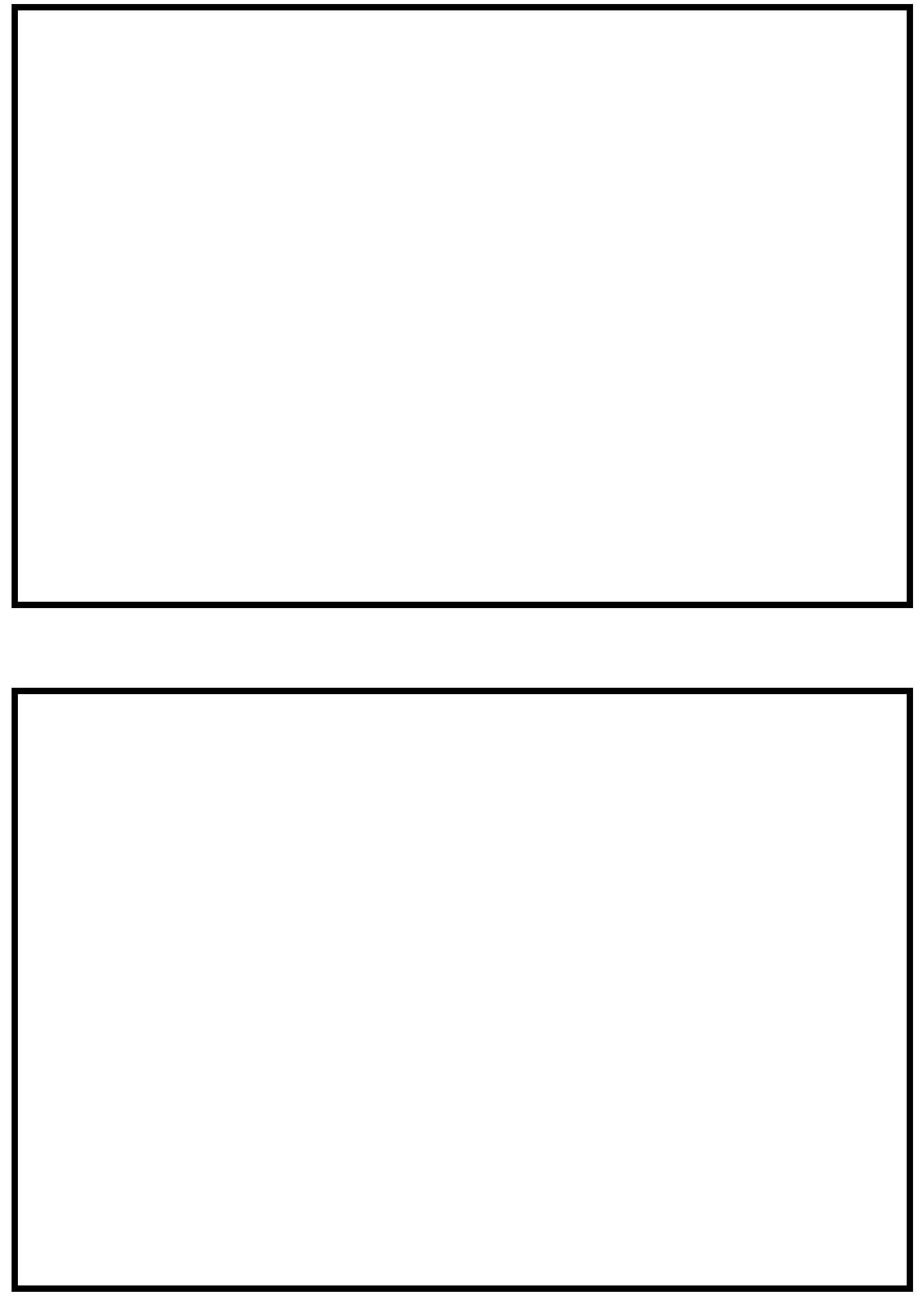


\section{LEVEL II SUMMARY}

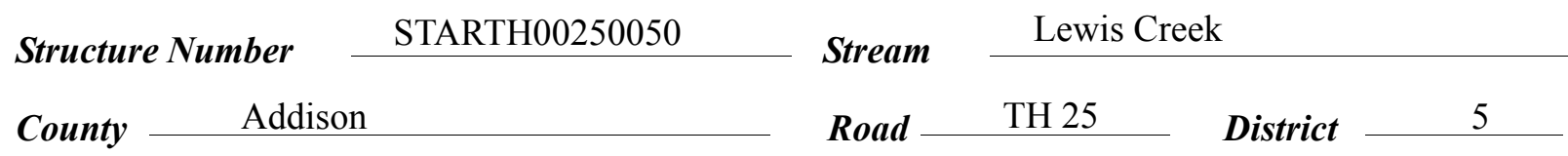

\section{Description of Bridge}

Bridge length $\frac{28}{2 t} \quad$ Bridge width $\frac{14.6}{f t}$ Max span length $\frac{25}{f t}$ Alignment of bridge to road (on curve or straight)

\begin{tabular}{llll} 
Abutment type & \multicolumn{2}{c}{ Vertical, concrete } & None \\
\cline { 2 - 2 } Stone fill on abutment? & Yes & Embankment type & $6 / 12 / 96$ \\
nato af incnortinn & Type-1, along the left abutment. Type-2, along the upstream right
\end{tabular}

wingwall, the right abutment, and the downstream right wingwall.

Abutments and wingwalls are concrete. There is a one

foot deep scour hole along the right abutment.

Is bridge skewed to flood flow according to Yes 'survey? Angle

There is a moderate channel bend in the downstream reach and a mild bend in the upstream reach. $6 / 12 / 96$

Debris accumulation on bridge at time of Level I or Level II site visit:

$$
\begin{gathered}
\text { Date af insnortion } \\
\underline{0}
\end{gathered} \quad \begin{gathered}
\text { Percent of ahrunal } \\
\text { blocked inortzontatly }
\end{gathered}
$$

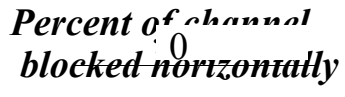$$
96
$$

Level I

Level II trees leaning over the channel upstream.

Potential for debris

0

\section{No \\ 0}

Percent of $6 / 12 /$
blocked verticatty

0

None as of 11/08/94.

Doscriho anv, fonturos noar ar at tho hridoo that mav, affort flou, (includo ahsorvation dato) 


\section{Description of the Geomorphic Setting}

General topography The channel is located within a moderate relief valley.

Geomorphic conditions at bridge site: downstream (DS), upstream (US)

Date of inspection $\quad 6 / 12 / 96$

DS left: $\quad$ Steep channel bank to a mildly sloped overbank

DS right: $\quad$ Steep channel bank to a moderately sloped overbank

US left: $\quad$ Low channel bank to a moderately sloped overbank

US right: $\quad$ Steep valley wall

\section{Description of the Channel}

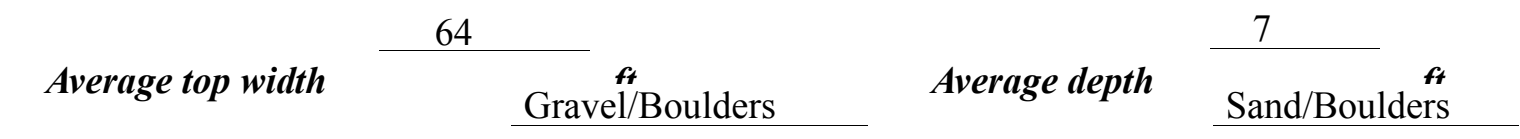

Predominant bed material Bank material Straight and stable

with semi-allúvial channel boundaries.

$6 / 12 / 96$

Vegetative co ${ }^{1}$ A few trees with grass on the overbank

DS left: $\quad$ Trees

DS right: $\quad$ A few trees with grass on the overbank

US left: $\quad$ Trees

US right: $\quad$ Yes

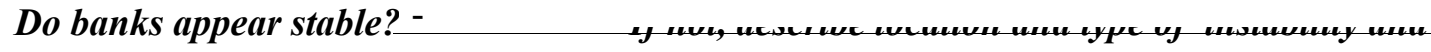

date of observation.

None as of 6/12/96.

Describe any obstructions in channel and date of observation. 


\title{
Hydrology
}

Drainage area $\frac{10.9}{\boldsymbol{m i}^{2}}$

Percentage of drainage area in physiographic provinces: (approximate)

Physiographic province/section

New England/Green Mountain
Percent of drainage area 100

\begin{abstract}
Is drainage area considered rural or urban?
Rural None.

urbanization:-
\end{abstract}

Yes

Is there a USGS gage on the stream of interest? Lewis Creek near North Ferrisburg, VT USGS gage description 04282780

USGS gage number 77.2

Gage drainage area $m i^{2}$ No

Is there a lake/p -

$$
\begin{aligned}
& \text { Calculated Discharges } \quad \underline{3,700} \\
& \text { Q100 } \quad \mathrm{ft}^{3} / \mathrm{s} \quad \mathbf{Q 5 0 0} \quad \mathrm{ft}^{3} / \mathrm{s}
\end{aligned}
$$

The 100- and 500-year discharges are based on a

drainage area relationship.[(10.9/8.9 2 exp 0.67] with bridge number 49 in Starksboro. Bridge number 49 crosses Lewis Creek upstream of this site and has flood frequency estimates available from the VTAOT database. The drainage area above bridge number 49 is 8.9 square miles. The values used were within a range defined by flood frequency curves developed from several empirical methods (Benson, 1962; Johnson and Tasker, 1974; FHWA, 1983; Potter, 1957a\&b; Talbot, 1887). 


\section{Description of the Water-Surface Profile Model (WSPRO) Analysis}

Datum for WSPRO analysis (USGS survey, sea level, VTAOT plans)

USGS survey

Datum tie between USGS survey and VTAOT plans

None

Description of reference marks used to determine USGS datum. $\quad$ RM1 is a chiseled X on

top of the downstream left corner of the bridge deck (elev. $498.51 \mathrm{ft}$, arbitrary survey datum).

$\mathrm{RM} 2$ is a nail five feet from the ground in a tree on the right bank $15 \mathrm{ft}$ upstream and $15 \mathrm{ft}$ from

the stream (elev. $498.33 \mathrm{ft}$, arbitrary survey datum).

\section{Cross-Sections Used in WSPRO Analysis}

\begin{tabular}{cccl}
\hline${ }^{1}$ Cross-section & $\begin{array}{c}\text { Section } \\
\text { Reference } \\
\text { Distance } \\
\text { (SRD) in feet }\end{array}$ & $\begin{array}{c}{ }^{2} \text { Cross-section } \\
\text { development }\end{array}$ & \multicolumn{1}{c}{ Comments } \\
\hline EXITX & -25 & 1 & Exit section \\
FULLV & 0 & 2 & $\begin{array}{l}\text { Downstream Full-valley } \\
\text { section (Templated from } \\
\text { EXITX) } \\
\text { BRIDG }\end{array}$ \\
RDWAY & 0 & 1 & Bridge section \\
APPRO & 8 & 1 & Road Grade section \\
& 38 & 1 & Approach section \\
\hline
\end{tabular}

${ }^{1}$ For location of cross-sections see plan-view sketch included with Level I field form, Appendix E. For more detail on how cross-sections were developed see WSPRO input file. 


\section{Data and Assumptions Used in WSPRO Model}

Hydraulic analyses of the reach were done by use of the Federal Highway Administration's WSPRO step-backwater computer program (Shearman and others, 1986, and Shearman, 1990). The analyses reported herein reflect conditions existing at the site at the time of the study. Furthermore, in the development of the model it was necessary to assume no accumulation of debris or ice at the site. Results of the hydraulic model are presented in the Bridge Hydraulic Summary, Appendix B, and figure 7.

Channel roughness factors (Manning's “ $n$ ”) used in the hydraulic model were estimated using field inspections at each cross section following the general guidelines described by Arcement and Schneider (1989). Final adjustments to the values were made during the modelling of the reach. Channel " $n$ " values for the reach ranged from 0.050 to 0.060 , and overbank " $n$ " values ranged from 0.035 to 0.080 .

Normal depth at the exit section (EXITX) was assumed as the starting water surface. This depth was computed by use of the slope-conveyance method outlined in the user's manual for WSPRO (Shearman, 1990). The slope used was $0.0067 \mathrm{ft} / \mathrm{ft}$, which was estimated from the topographic map (U.S. Geological Survey, 1963).

The modelled approach section (APPRO) was surveyed one bridge length upstream of the upstream face as recommended by Shearman and others (1986). This location provides a consistent method for determining scour variables. 


\section{Bridge Hydraulics Summary}

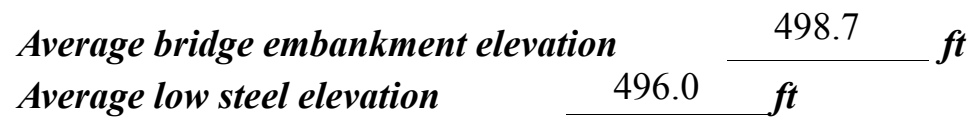

100-year discharge $\quad 2,590 \quad \mathrm{ft}^{3} / \mathrm{s}$

Water-surface elevation in bridge opening $\quad 496.1 \quad f t$

Road overtopping? ___ Yes Discharge over road ___ $\quad \mathrm{ft}^{3} / \mathrm{s}$

Area of flow in bridge opening $\quad 246 \quad \mathrm{ft}^{2}$

Average velocity in bridge opening $10.5 \quad \mathrm{ft} / \mathrm{s}$

$\begin{array}{llll}\text { Maximum WSPRO tube velocity at bridge } & 13.3 \mathrm{ft} / \mathrm{s}\end{array}$

Water-surface elevation at Approach section with bridge 498.7

Water-surface elevation at Approach section without bridge $\quad 494.5$

Amount of backwater caused by bridge

4.2 it

500-year discharge $\quad 3,700 \quad f^{3} / s$

Water-surface elevation in bridge opening $496.0 \mathrm{ft}$

$\begin{array}{llllll}\text { Road overtopping? ___ Yes Discharge over road __ } & 452 & \mathrm{ft}^{3} / \mathrm{s}\end{array}$

Area of flow in bridge opening $\quad 245 \quad \mathrm{ft}^{2}$

Average velocity in bridge opening $13.3 \mathrm{ft} / \mathrm{s}$

Maximum WSPRO tube velocity at bridge 18.5 's

Water-surface elevation at Approach section with bridge

Water-surface elevation at Approach section without bridge

Amount of backwater caused by bridge $\quad 3.8$,t

500.1

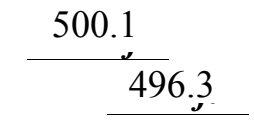

Incipient overtopping discharge $\quad 2,570 \mathrm{ft}^{3} / \mathrm{s}$

Water-surface elevation in bridge opening $496.1 \quad t$

Area of flow in bridge opening $\quad 246 \quad \mathrm{ft}^{2}$

Average velocity in bridge opening $\quad 10.5 \quad \mathrm{ft} / \mathrm{s}$

Maximum WSPRO tube velocity at bridge $\quad 13.2 \mathrm{ft} / \mathrm{s}$

Water-surface elevation at Approach section with bridge

Water-surface elevation at Approach section without bridge

Amount of backwater caused by bridge

$4.1 . t$

498.6

494.5 


\section{Scour Analysis Summary}

\section{Special Conditions or Assumptions Made in Scour Analysis}

Scour depths were computed using the general guidelines described in Hydraulic Engineering Circular 18 (Richardson and others, 1995). Scour depths were calculated assuming an infinite depth of erosive material and a homogeneous particle-size distribution. The results of the scour analysis for the 100-year and 500-year discharges are presented in tables 1 and 2 and a graph of the scour depths is presented in figure 8 .

At this site, the 100-year and incipient roadway-overtopping discharges resulted in unsubmerged orifice flow and the 500-year discharge resulted in submerged orifice flow. Contraction scour at bridges with orifice flow is best estimated by use of the Chang pressureflow scour equation (oral communication, J. Sterling Jones, October 4, 1996). Thus, contraction scour for these discharges was computed by use of the Chang equation (Richardson and others, 1995, p. 145-146). The computed streambed armoring depths suggest that armoring will not limit the depth of contraction scour.

For comparison, contraction scour for the discharges resulting in orifice flow was also computed by use of the Laursen clear-water contraction scour equation (Richardson and others, 1995, p. 32, equation 20) and the Umbrell pressure-flow equation (Richardson and others, 1995, p. 144) and the results are presented in Appendix F. Furthermore, for the 100year and incipient roadway-overtopping discharges, contraction scour was computed by substituting estimates for the depth of flow at the downstream bridge face in the contraction scour equations. Results with respect to these substitutions are provided in Appendix F.

Abutment scour was computed by use of the Froehlich equation (Richardson and others, 1995, p. 48, equation 28). Variables for the Froehlich equation include the Froude number of the flow approaching the embankments, the length of the embankment blocking flow, and the depth of flow approaching the embankment less any roadway overtopping. 


\section{Scour Results}

$$
\text { 100-yr discharge 500-yrdischarge }
$$

(Scour depths in feet)

Main channel

Live-bed scour

Clear-water scour

Depth to armoring

Left overbank

Right overbank

Local scour:

Abutment scour

Left abutment

Right abutment

Pier scour

Pier 1

Pier 2

Pier 3
17.1

$13.1-$

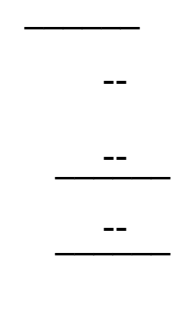

\section{Riprap Sizing}

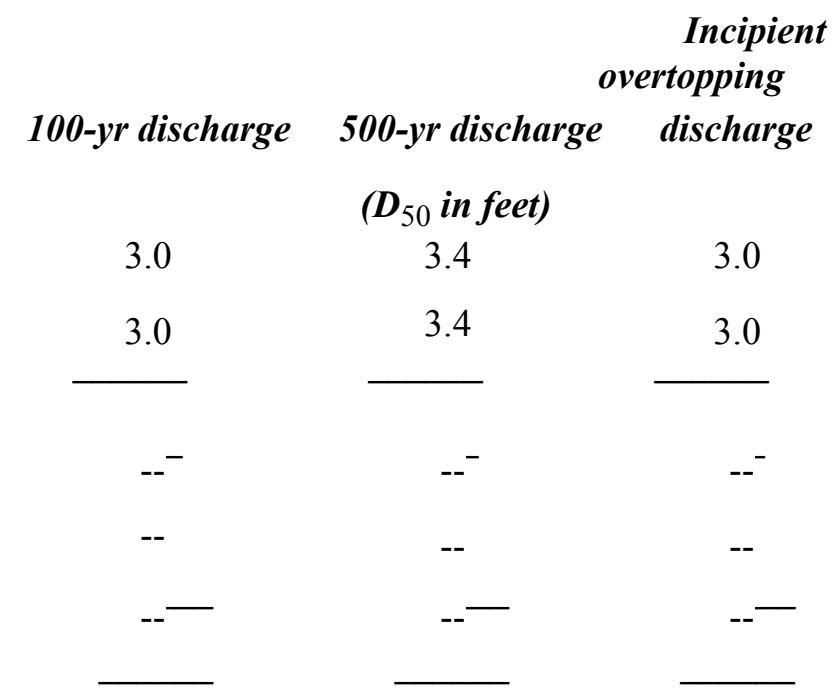




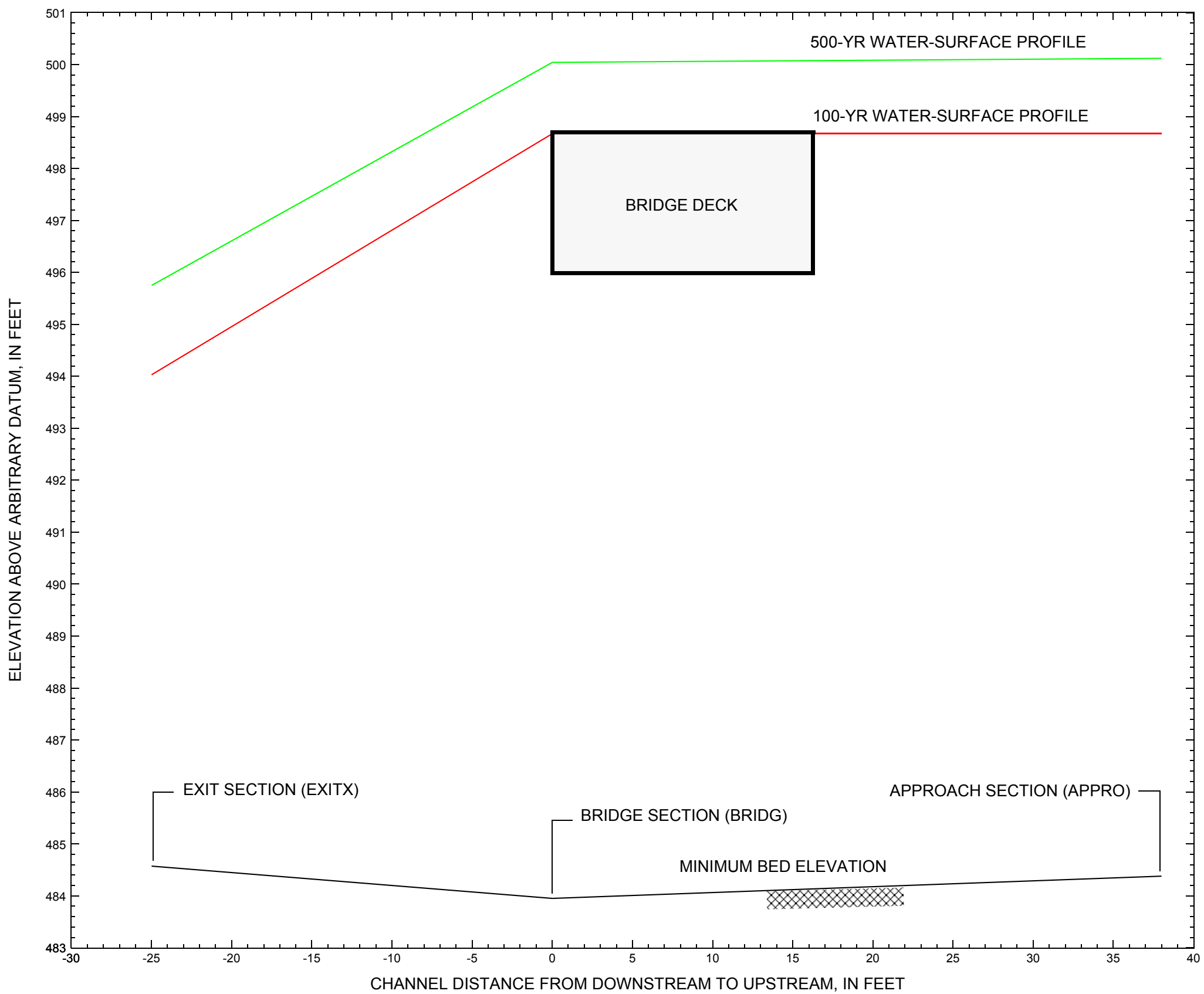

Figure 7. Water-surface profiles for the 100- and 500-yr discharges at structure STARTH00250050 on Town Highway 25, crossing Lewis Creek, Starksboro, Vermont. 


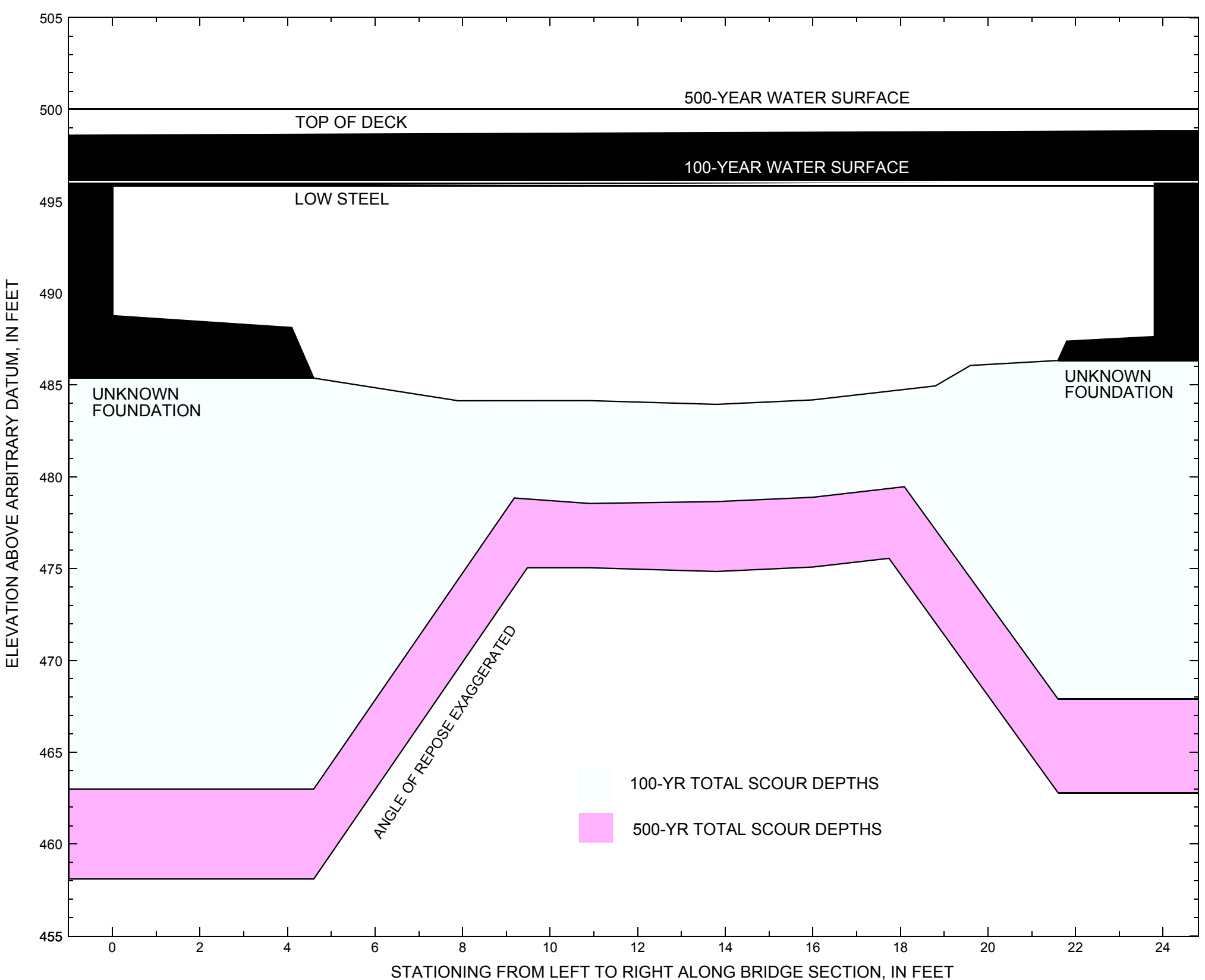

Figure 8. Scour elevations for the 100-yr and 500-yr discharges at structure STARTH00250050 on Town Highway 25, crossing Lewis Creek, Starksboro, Vermont. 
Table 1. Remaining footing/pile depth at abutments for the 100-year discharge at structure STARTH00250050 on Town Highway 25, crossing Lewis Creek, Starksboro, Vermont.

[VTAOT, Vermont Agency of Transportation; --, no data]

\begin{tabular}{|c|c|c|c|c|c|c|c|c|c|c|c|}
\hline Description & Station $^{1}$ & $\begin{array}{l}\text { VTAOT } \\
\text { minimum } \\
\text { low-chord } \\
\text { elevation } \\
\text { (feet) }\end{array}$ & $\begin{array}{l}\text { Surveyed } \\
\text { minimum } \\
\text { low-chord } \\
\text { elevation } \\
\text { (feet) }\end{array}$ & $\begin{array}{c}\text { Bottom of } \\
\text { footing/pile } \\
\text { elevation }{ }^{2} \\
\text { (feet) }\end{array}$ & $\begin{array}{l}\text { Channel } \\
\text { elevation at } \\
\text { abutment/ } \\
\text { pier }^{2} \\
\text { (feet) }\end{array}$ & $\begin{array}{l}\text { Contraction } \\
\text { scour depth } \\
\text { (feet) }\end{array}$ & $\begin{array}{l}\text { Abutment } \\
\text { scour } \\
\text { depth } \\
\text { (feet) }\end{array}$ & $\begin{array}{l}\text { Pier } \\
\text { scour } \\
\text { depth } \\
\text { (feet) }\end{array}$ & $\begin{array}{l}\text { Depth of } \\
\text { total scour } \\
\text { (feet) }\end{array}$ & $\begin{array}{c}\text { Elevation of } \\
\text { scour }^{2} \\
\text { (feet) }\end{array}$ & $\begin{array}{c}\text { Remaining } \\
\text { footing/pile } \\
\text { depth } \\
\text { (feet) }\end{array}$ \\
\hline \multicolumn{12}{|c|}{100 -yr. discharge is 2,590 cubic-feet per second } \\
\hline Left abutment & 0.0 & -- & 495.8 & -- & 485.4 & 5.3 & 17.1 & -- & 22.4 & 463.0 & -- \\
\hline Right abutment & 23.8 & -- & 496.1 & -- & 486.3 & 5.3 & 13.1 & -- & 18.4 & 467.9 & -- \\
\hline
\end{tabular}

1.Measured along the face of the most constricting side of the bridge.

2.Arbitrary datum for this study.

Table 2. Remaining footing/pile depth at abutments for the 500-year discharge at structure STARTH00250050 on Town Highway 25, crossing Lewis Creek, Starksboro, Vermont.

[VTAOT, Vermont Agency of Transportation; --, no data]

\begin{tabular}{|c|c|c|c|c|c|c|c|c|c|c|c|}
\hline Description & Station $^{1}$ & $\begin{array}{l}\text { VTAOT } \\
\text { minimum } \\
\text { low-chord } \\
\text { elevation } \\
\text { (feet) }\end{array}$ & $\begin{array}{c}\text { Surveyed } \\
\text { minimum } \\
\text { low-chord } \\
\text { elevation } \\
\text { (feet) }\end{array}$ & $\begin{array}{c}\text { Bottom of } \\
\text { footing/pile } \\
\text { elevation } \\
\text { (feet) }\end{array}$ & $\begin{array}{c}\text { Channel } \\
\text { elevation at } \\
\text { abutment/ } \\
\text { pier }^{2} \\
\text { (feet) }\end{array}$ & $\begin{array}{l}\text { Contraction } \\
\text { scour depth } \\
\text { (feet) }\end{array}$ & $\begin{array}{c}\text { Abutment } \\
\text { scour } \\
\text { depth } \\
\text { (feet) }\end{array}$ & $\begin{array}{l}\text { Pier } \\
\text { scour } \\
\text { depth } \\
\text { (feet) }\end{array}$ & $\begin{array}{l}\text { Depth of } \\
\text { total scour } \\
\text { (feet) }\end{array}$ & $\begin{array}{c}\text { Elevation of } \\
\text { scour }^{2} \\
\text { (feet) }\end{array}$ & $\begin{array}{c}\text { Remaining } \\
\text { footing/pile } \\
\text { depth } \\
\text { (feet) }\end{array}$ \\
\hline \multicolumn{12}{|c|}{500 -yr. discharge is 3,700 cubic-feet per second } \\
\hline Left abutment & 0.0 & -- & 495.8 & -- & 485.4 & 9.1 & 18.2 & -- & 27.3 & 458.1 & -- \\
\hline Right abutment & 23.8 & -- & 496.1 & -- & 486.3 & 9.1 & 14.4 & -- & 23.5 & 462.8 & -- \\
\hline
\end{tabular}

1.Measured along the face of the most constricting side of the bridge.

2.Arbitrary datum for this study. 


\section{SELECTED REFERENCES}

Arcement, G.J., Jr., and Schneider, V.R., 1989, Guide for selecting Manning's roughness coefficients for natural channels and flood plains: U.S. Geological Survey Water-Supply Paper 2339, 38 p.

Barnes, H.H., Jr., 1967, Roughness characteristics of natural channels: U.S. Geological Survey Water-Supply Paper 1849,213 p.

Benson, M. A., 1962, Factors Influencing the Occurrence of Floods in a Humid Region of Diverse Terrain: U.S. Geological Survey WaterSupply Paper 1580-B, 64 p.

Brown, S.A. and Clyde, E.S., 1989, Design of riprap revetment: Federal Highway Administration Hydraulic Engineering Circular No. 11, Publication FHWA-IP-89-016, 156 p.

Federal Highway Administration, 1983, Runoff estimates for small watersheds and development of sound design: Federal Highway Administration Report FHWA-RD-77-158.

Federal Highway Administration, 1993, Stream Stability and Scour at Highway Bridges: Participant Workbook: Federal Highway Administration Report FHWA-HI-91-011.

Froehlich, D.C., 1989, Local scour at bridge abutments in Ports, M.A., ed., Hydraulic Engineering--Proceedings of the 1989 National Conference on Hydraulic Engineering: New York, American Society of Civil Engineers, p. 13-18.

Hayes, D.C.,1993, Site selection and collection of bridge-scour data in Delaware, Maryland, and Virginia: U.S. Geological Survey WaterResources Investigation Report 93-4017, 23 p.

Interagency Advisory Committee on Water Data, 1982, Guidelines for determining flood flow frequency: U.S. Geological Survey, Bulletin 17B of the Hydrology Subcommittee, 190 p.

Johnson, C.G. and Tasker, G.D.,1974, Progress report on flood magnitude and frequency of Vermont streams: U.S. Geological Survey OpenFile Report 74-130, 37 p.

Lagasse, P.F., Schall, J.D., Johnson, F., Richardson, E.V., Chang, F., 1995, Stream Stability at Highway Structures: Federal Highway Administration Hydraulic Engineering Circular No. 20, Publication FHWA-IP-90-014, 144 p.

Laursen, E.M., 1960, Scour at bridge crossings: Journal of the Hydraulics Division, American Society of Civil Engineers, v. 86, no. HY2, p. 39-53.

Potter, W. D., 1957a, Peak rates of runoff in the Adirondack, White Mountains, and Maine woods area, Bureau of Public Roads

Potter, W. D., 1957b, Peak rates of runoff in the New England Hill and Lowland area, Bureau of Public Roads

Richardson, E.V. and Davis, S.R., 1995, Evaluating scour at bridges: Federal Highway Administration Hydraulic Engineering Circular No. 18, Publication FHWA-IP-90-017, 204 p.

Richardson, E.V., Simons, D.B., and Julien, P.Y., 1990, Highways in the river environment: Federal Highway Administration Publication FHWA-HI-90-016.

Ritter, D.F., 1984, Process Geomorphology: W.C. Brown Co., Debuque, Iowa, 603 p.

Shearman, J.O., 1990, User's manual for WSPRO--a computer model for water surface profile computations: Federal Highway Administration Publication FHWA-IP-89-027, 187 p.

Shearman, J.O., Kirby, W.H., Schneider, V.R., and Flippo, H.N., 1986, Bridge waterways analysis model; research report: Federal Highway Administration Publication FHWA-RD-86-108, 112 p.

Talbot, A.N., 1887, The determination of water-way for bridges and culverts.

U.S. Department of Transportation, 1993, Stream stability and scour at highway bridges, Participant Workbook: Federal Highway Administration Publication FHWA HI-91-011.

U.S. Geological Survey, 1963, Bristol, Vermont 7.5 Minute Series quadrangle map: U.S. Geological Survey Topographic Maps, Scale 1:24,000. 


\section{APPENDIX A: \\ WSPRO INPUT FILE}




\section{WSPRO INPUT FILE}

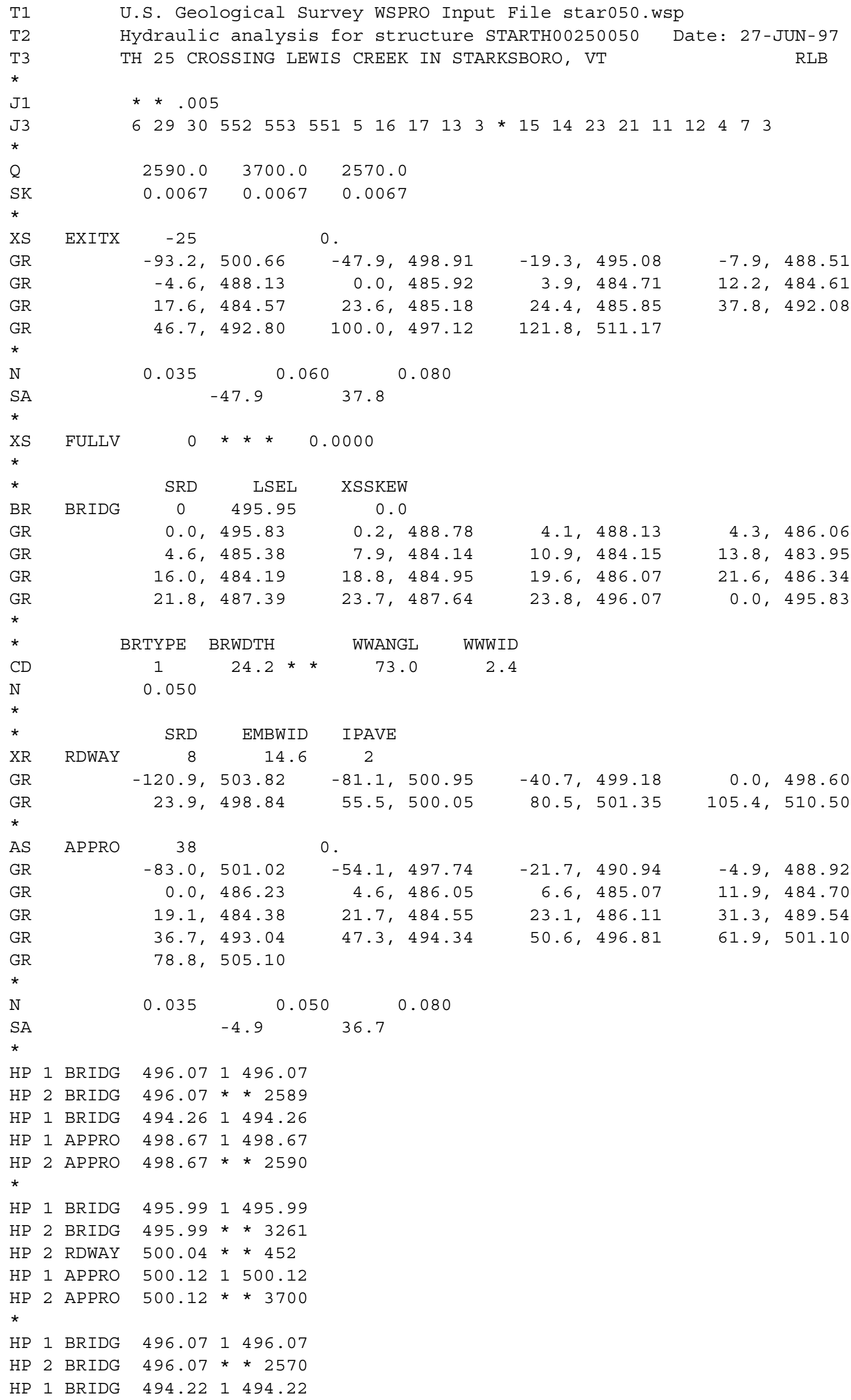




\section{APPENDIX B: \\ WSPRO OUTPUT FILE}


WSPRO OUTPUT FILE

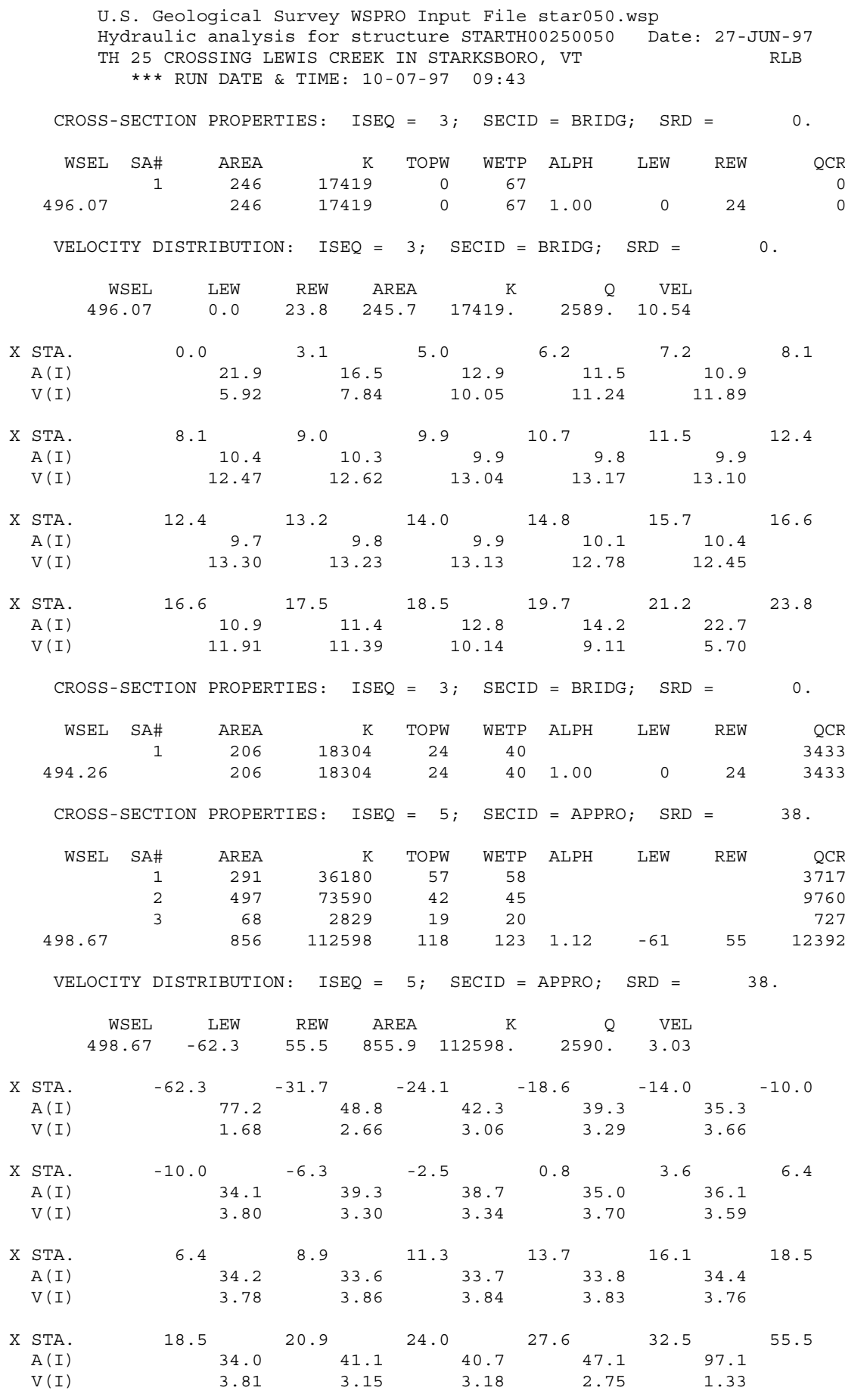


WSPRO OUTPUT FILE (continued)

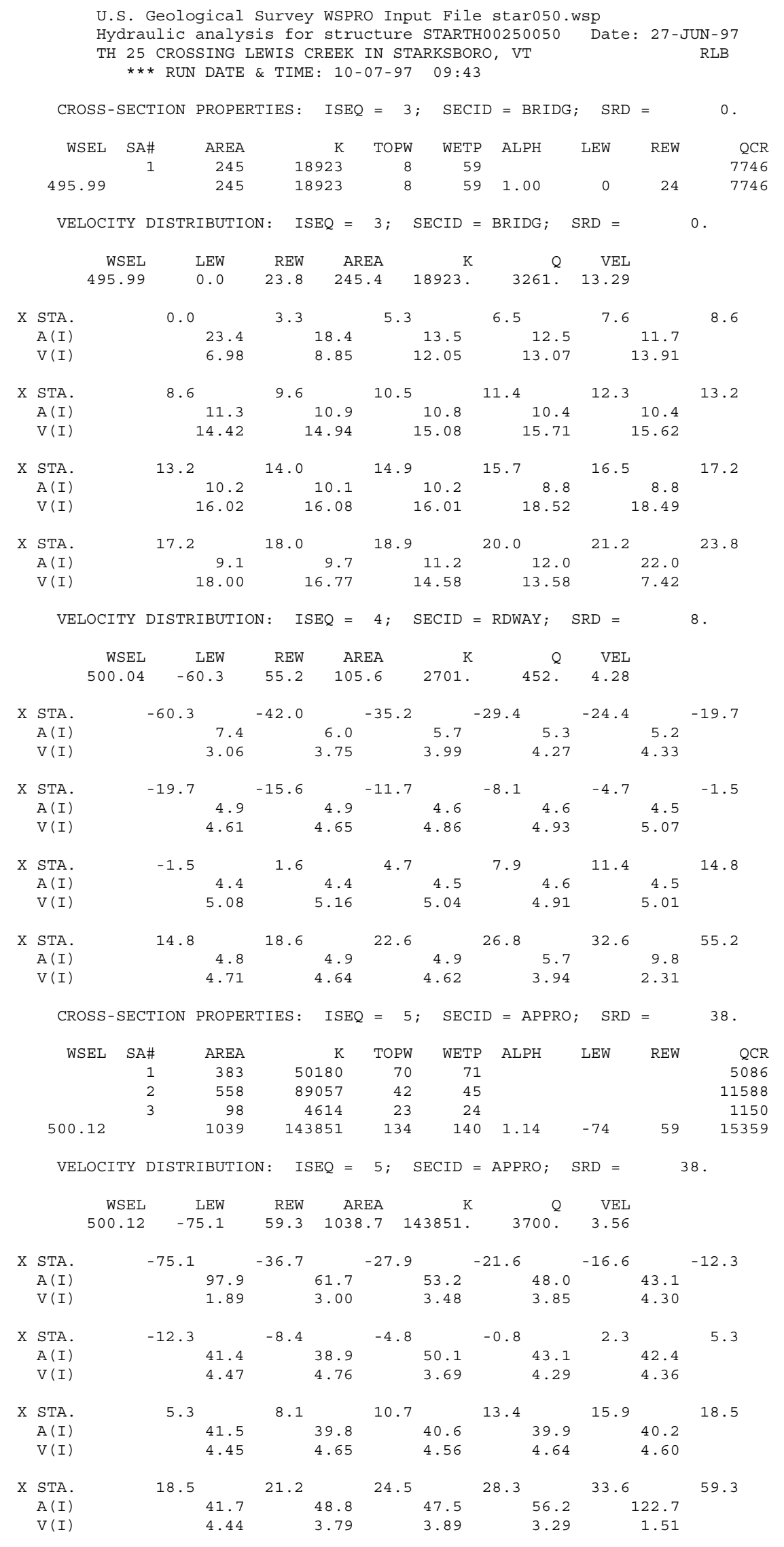


WSPRO OUTPUT FILE (continued)

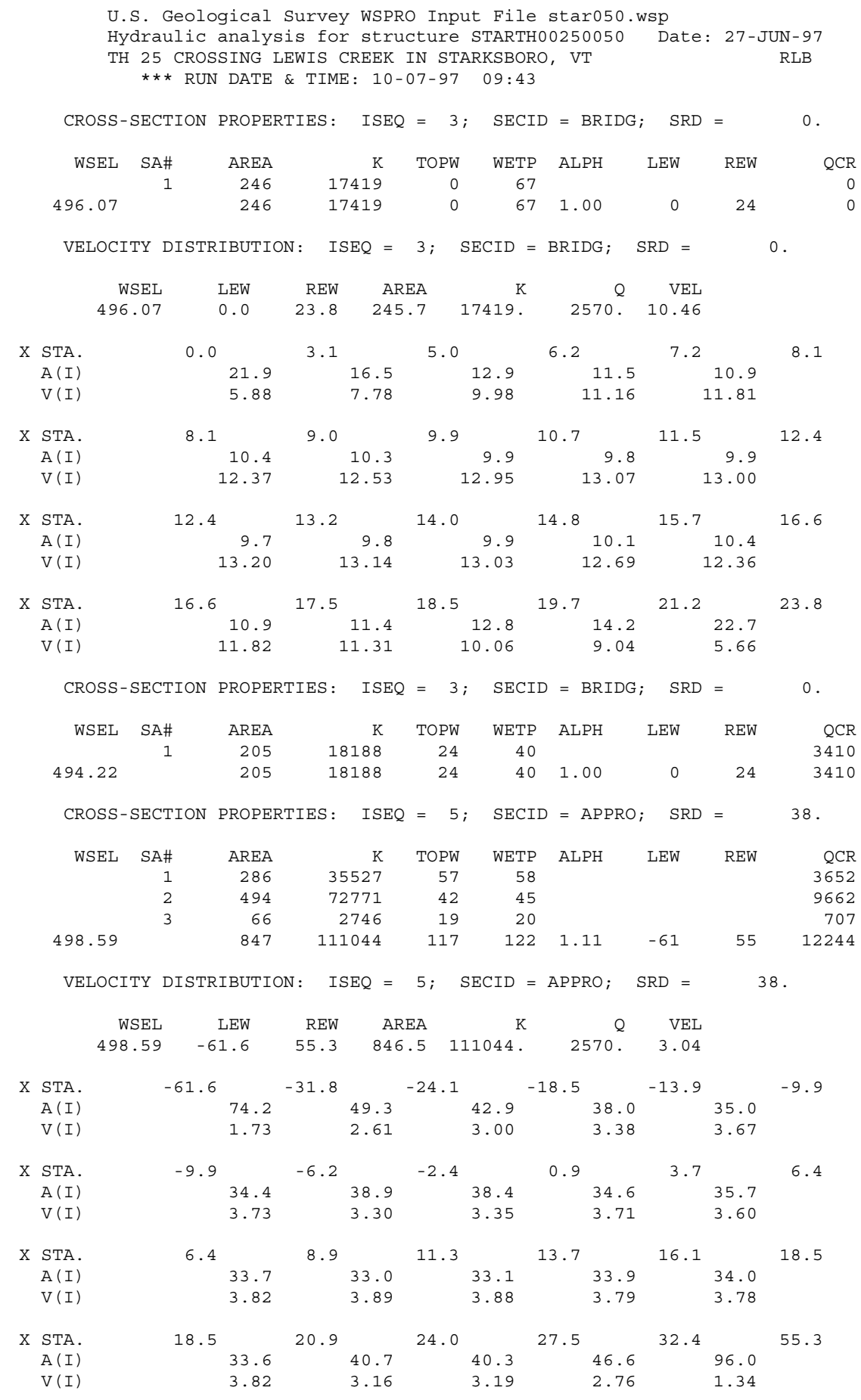


WSPRO OUTPUT FILE (continued)

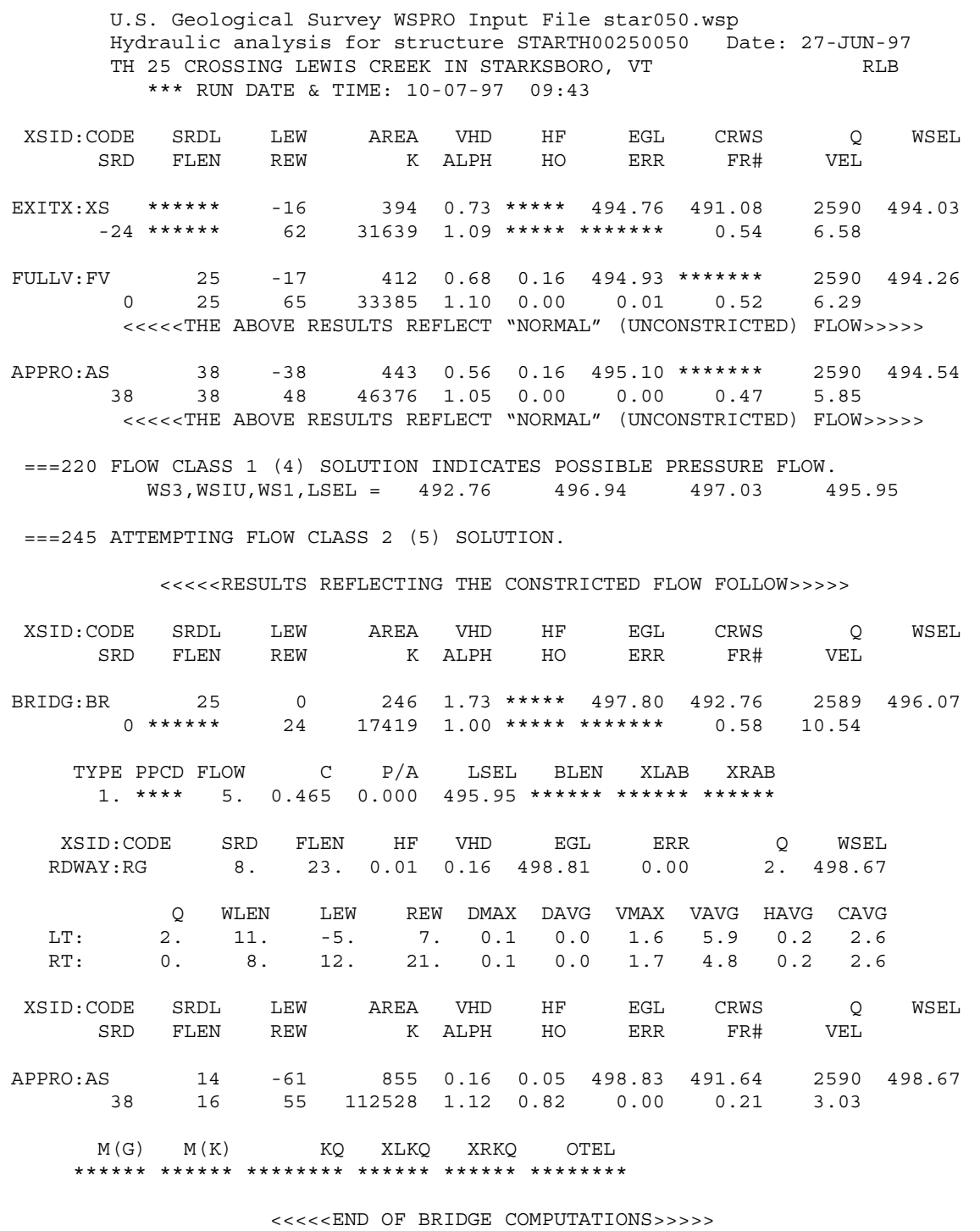

FIRST USER DEFINED TABLE.

\begin{tabular}{|c|c|c|c|c|c|c|c|c|}
\hline XSID : CODE & SRD & LEW & REW & Q & $\mathrm{K}$ & AREA & VEL & WSEL \\
\hline EXITX:XS & -25 & -17 & 62. & 2590 . & 31639. & 394. & 6.58 & 494.03 \\
\hline FULLV : FV & 0 & -18 & 65. & 2590 . & 33385 . & 412 . & 6.29 & 494.26 \\
\hline BRIDG : BR & 0. & 0 & 24. & 2589. & 17419 . & 246 . & 10.54 & 496.07 \\
\hline RDWAY : RG & $8 . *$ & $\star \star \star \star * \star$ & 2 . & 2. & 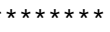 & 0 & 2.00 & 498.67 \\
\hline APPRO : AS & 38. & -62 & 55. & 2590 . & 112528. & 855. & 3.03 & 498.67 \\
\hline XSID : CODE & XLKQ & $\mathrm{XRKQ}$ & & & & & & \\
\hline
\end{tabular}

SECOND USER DEFINED TABLE.

$\begin{array}{lcrrrrrrrr}\text { XSID : CODE } & \text { CRWS } & \text { FR\# } & \text { YMIN } & \text { YMAX } & \text { HF } & \text { HO } & \text { VHD } & \text { EGL } & \text { WSEL } \\ \text { EXITX: }: \text { S } & 491.08 & 0.54 & 484.57 & 511.17 * * * * * * * * * * & 0.73 & 494.76 & 494.03 \\ \text { FULLV :FV } & * * * * * * * * & 0.52 & 484.57 & 511.17 & 0.16 & 0.00 & 0.68 & 494.93 & 494.26 \\ \text { BRIDG : BR } & 492.76 & 0.58 & 483.95 & 496.07 * * * * * * * * * * * & 1.73 & 497.80 & 496.07 \\ \text { RDWAY: RG } & * * * * * * * * * * * * * * * & 498.60 & 510.50 & 0.01 * * * * * * & 0.16 & 498.81 & 498.67 \\ \text { APPRO:AS } & 491.64 & 0.21 & 484.38 & 505.10 & 0.05 & 0.82 & 0.16 & 498.83 & 498.67\end{array}$


WSPRO OUTPUT FILE (continued)

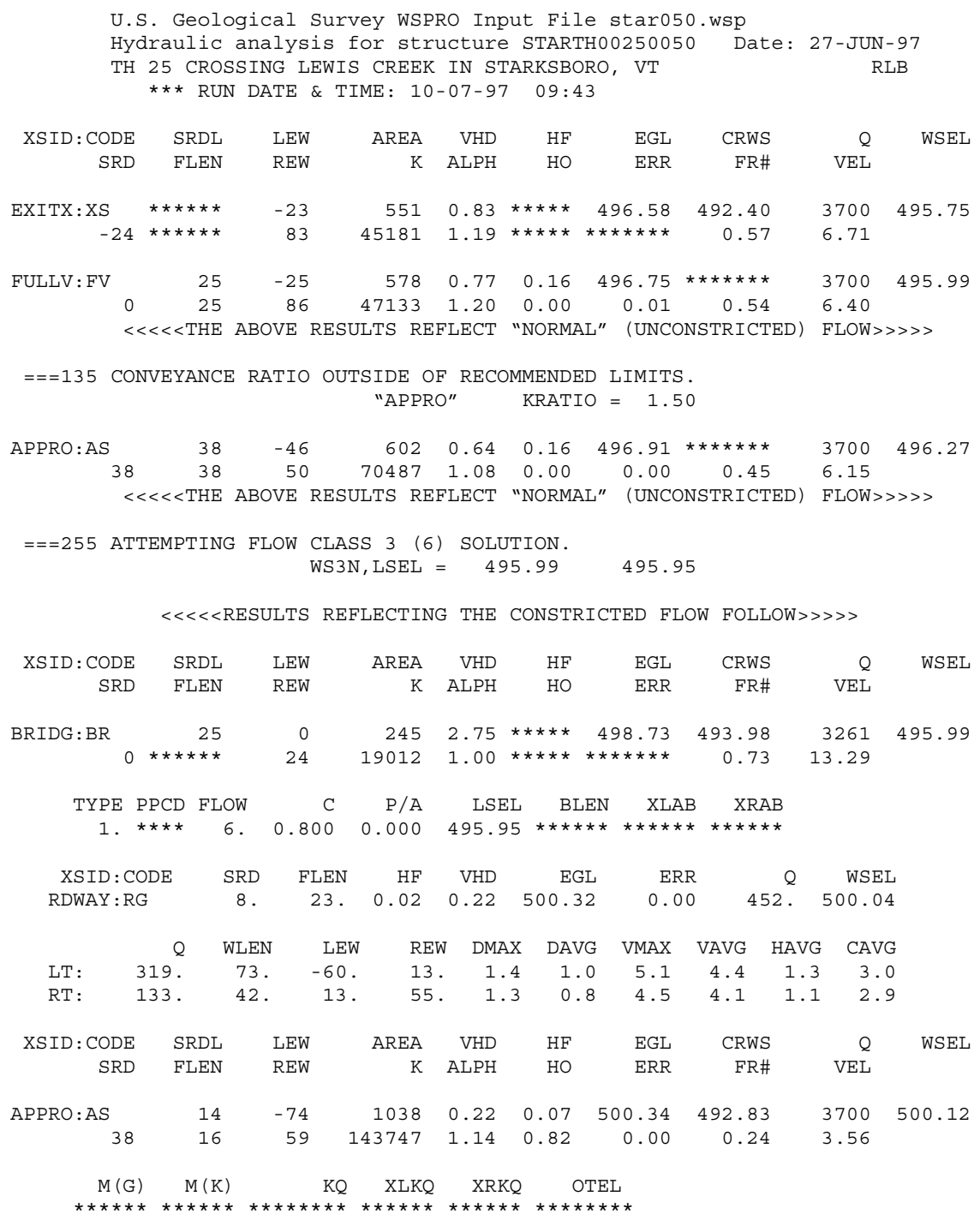

$<<<<$ END OF BRIDGE COMPUTATIONS $>>>>>$

FIRST USER DEFINED TABLE.

\begin{tabular}{|c|c|c|c|c|c|c|c|c|}
\hline XSID : CODE & SRD & LEW & REW & 0 & $\mathrm{~K}$ & AREA & VEL & WSEL \\
\hline EXITX:XS & -25 & -24 & 83. & 3700 . & 45181. & 551. & 6.71 & 495.75 \\
\hline FULLV : FV & 0 . & -26 & 86. & 3700 . & 47133. & 578. & 6.40 & 495.99 \\
\hline BRIDG : BR & 0 . & 0 & 24. & 3261. & 19012 . & 245 . & 13.29 & 495.99 \\
\hline RDWAY : RG & 8. * & $\star \star \star \star \star *$ & 319. & 452 . & 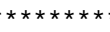 & $* * * * *$ & 2.00 & 500.04 \\
\hline APPRO : AS & 38. & -75 & 59. & 3700 . & 143747 . & 1038. & 3.56 & 500.12 \\
\hline XSID : CODE & XLKQ & $\mathrm{XRKQ}$ & & & & & & \\
\hline
\end{tabular}

SECOND USER DEFINED TABLE.

$\begin{array}{lcrrrrrrrr}\text { XSID : CODE } & \text { CRWS } & \text { FR\# } & \text { YMIN } & \text { YMAX } & \text { HF } & \text { HO } & \text { VHD } & \text { EGL } & \text { WSEL } \\ \text { EXITX :XS } & 492.40 & 0.57 & 484.57 & 511.17 * * * * * * * * * * * & 0.83 & 496.58 & 495.75 \\ \text { FULLV :FV } & * * * * * * * & 0.54 & 484.57 & 511.17 & 0.16 & 0.00 & 0.77 & 496.75 & 495.99 \\ \text { BRIDG :BR } & 493.98 & 0.73 & 483.95 & 496.07 * * * * * * * * * * * & 2.75 & 498.73 & 495.99 \\ \text { RDWAY :RG } & * * * * * * * * * * * * * * & 498.60 & 510.50 & 0.02 * * * * * * & 0.22 & 500.32 & 500.04 \\ \text { APPRO :AS } & 492.83 & 0.24 & 484.38 & 505.10 & 0.07 & 0.82 & 0.22 & 500.34 & 500.12\end{array}$


WSPRO OUTPUT FILE (continued)

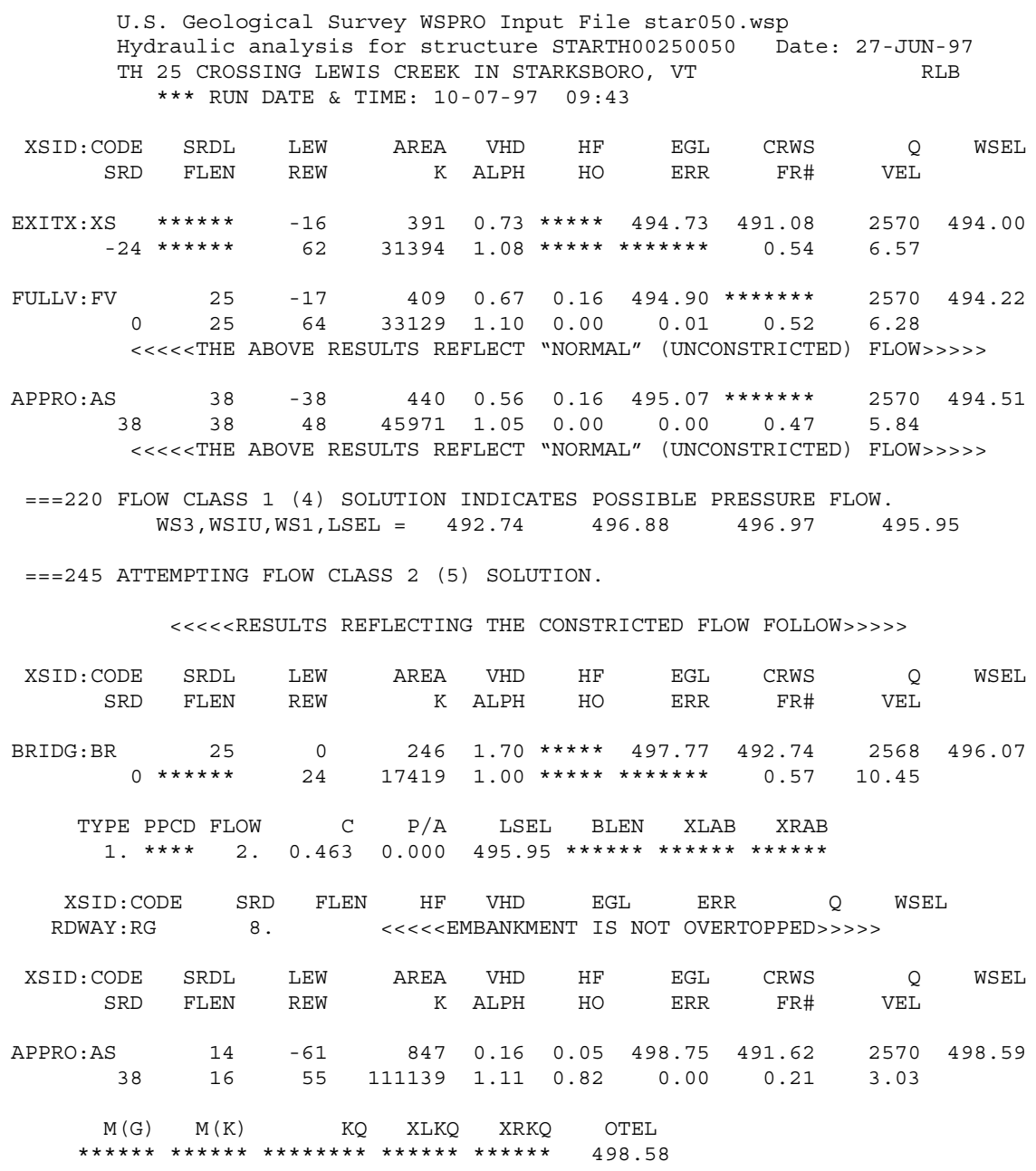

$<<<<$ END OF BRIDGE COMPUTATIONS $>>>>>$

FIRST USER DEFINED TABLE.

\begin{tabular}{|c|c|c|c|c|c|c|c|c|}
\hline XSID : CODE & SRD & LEW & REW & $\mathrm{Q}$ & $\mathrm{K}$ & AREA & VEL & WSEL \\
\hline EXITX:XS & -25 & -17 & 62. & 2570 . & 31394 . & 391. & 6.57 & 494.00 \\
\hline FULLV : FV & 0. & -18. & 64. & 2570 . & 33129 . & 409. & 6.28 & 494.22 \\
\hline $\mathrm{BRIDG}: \mathrm{BR}$ & 0 . & 0 . & 24 . & 2568 . & 17419. & 246 . & 10.45 & 496.07 \\
\hline RDWAY : RG & \multicolumn{3}{|c|}{$8 . * * * \star * * * \star * * * * * *$} & \multicolumn{2}{|c|}{$0 . * * * * * * * * *$} & 0 . & \multicolumn{2}{|c|}{$2.00 * * * * * * * *$} \\
\hline APPRO : AS & 38. & -62 & 55. & 2570 . & 111139. & 847. & 3.03 & 498.59 \\
\hline XSID : CODE & XLKQ & XRKQ & & & & & & \\
\hline PPRO : AS & & & & & & & & \\
\hline
\end{tabular}

SECOND USER DEFINED TABLE.

$\begin{array}{lcrrrrrrrr}\text { XSID :CODE } & \text { CRWS } & \text { FR\# } & \text { YMIN } & \text { YMAX } & \text { HF } & \text { HO } & \text { VHD } & \text { EGL } & \text { WSEL } \\ \text { EXITX:XS } & 491.08 & 0.54 & 484.57 & 511.17 * * * * * * * * * * & 0.73 & 494.73 & 494.00 \\ \text { FULLV:FV } & * * * * * * * * & 0.52 & 484.57 & 511.17 & 0.16 & 0.00 & 0.67 & 494.90 & 494.22 \\ \text { BRIDG : BR } & 492.74 & 0.57 & 483.95 & 496.07 * * * * * * * * * * * & 1.70 & 497.77 & 496.07 \\ \text { RDWAY: RG } & * * * * * * * * * * * * * * * * & 498.60 & 510.50 * * * * * * * * * * * * & 0.16 & 498.81 * * * * * * * \\ \text { APPRO:AS } & 491.62 & 0.21 & 484.38 & 505.10 & 0.05 & 0.82 & 0.16 & 498.75 & 498.59\end{array}$




\section{APPENDIX C:}

\section{BED-MATERIAL PARTICLE-SIZE DISTRIBUTION}




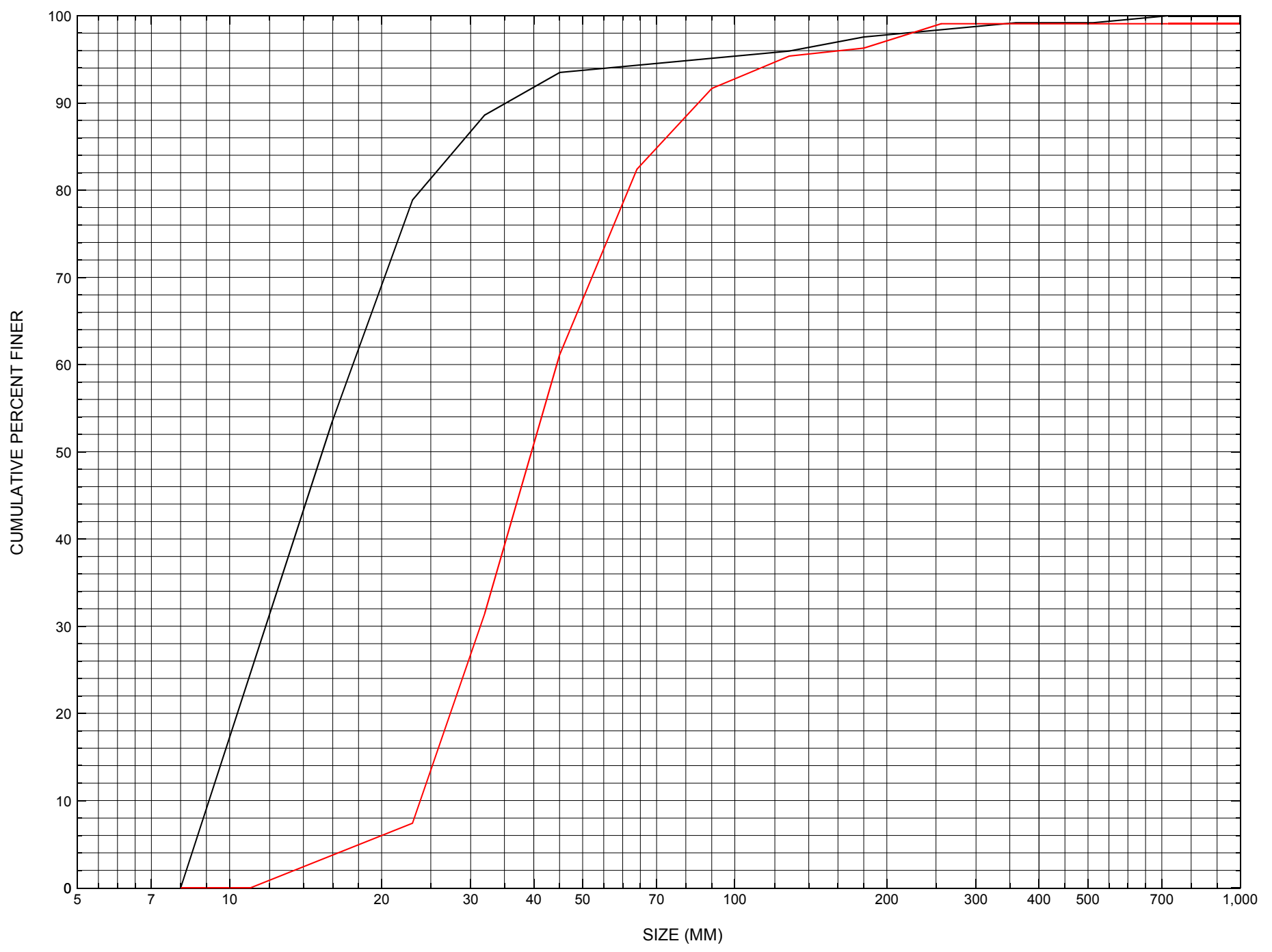

Appendix C. Bed material particle-size distribution for two pebble counts in the channel approach of structure STARTH00250050, in Starksboro, Vermont. 


\section{APPENDIX D: \\ HISTORICAL DATA FORM}




\section{Structure Number STARTH00250050}

\section{General Location Descriptive}

Data collected by (First Initial, Full last name) $\underline{\mathbf{L}}$. Medalie

Date $(M M / D D / Y Y)+12 / 15 / 95$

Highway District Number (I - 2; nn) $\mathbf{0 5}$

Town (FIPS place code; I - 4; nnnnn) $\mathbf{7 0 0 7 5}$

Waterway (I - 6) LEWIS CREEK

Route Number C3025

Topographic Map Bristol

Latitude (I - 16; nnnn.n) 44129
County (FIPS county code; I - 3; nnn) $\mathbf{0 0 1}$

Mile marker (I - 11; nnn.nnn) $\underline{000000}$

Road Name (I - 7): -

Vicinity (I - 9) 0.3 MI TO JCT W VT116

Hydrologic Unit Code: 2010002

Longitude (i - 17; nnnnn.n) $\mathbf{7 3 0 3 7}$

\section{Select Federal Inventory Codes}

FHWA Structure Number $(I-8) \quad 10011900500119$

Maintenance responsibility $(I-21 ; n n) \quad \mathbf{0 3}$

Year built (I - 27; YYYY) 1952

Average daily traffic, ADT (I - 29; nnnnnn) $\underline{\mathbf{0 0 0 0 1 0}}$

Year of ADT (I - 30; YY) $\mathbf{9 2}$

Opening skew to Roadway $(I-34 ; n n) \quad \mathbf{0 0}$

Operational status $(I-41 ; X) \quad \mathbf{A}$

Structure type (I - 43; nnn) $\mathbf{3 0 2}$

Approach span structure type $(I-44 ; n n n) \quad \mathbf{0 0 0}$

Number of spans (I - 45; nnn) 001

Number of approach spans (I - 46; nnnn) $\mathbf{0 0 0 0}$

Comments:

According to the structural inspection report dated 11/4/94, the abutments and a portion of the wingwalls are concrete. The upper parts of the abutments, between the beams, form a backwall. There are some cracks and areas of fine map cracking in the abutments. There is some horizontal cracking at the inter-
Maximum span length (I - 48; nnnn) $\underline{\mathbf{0 0 2 5}}$

Structure length (I - 49; nnnnnn) $\underline{\mathbf{0 0 0 0 2 8}}$

Deck Width (I - 52; nn.n) 146

Channel \& Protection $(I-61 ; n) \underline{5}$

Waterway adequacy $(I-71 ; n)$

Underwater Inspection Frequency (I - 92B; XYY) _ N

Year Reconstructed (I - 106) 1975

Clear span (nnn.nft) $\mathbf{2 1 . 5 8}$

Vertical clearance from streambed (nnn.nft) 10.32

Waterway of full opening $\left(n n n . n \mathrm{ft}^{2}\right) \underline{\mathbf{2 2 2 . 8}}$ 


\section{Bridge Hydrologic Data}

Is there hydrologic data available? fac if No, type ctrl- $n h \quad$ VTAOT Drainage area $\left(m i^{2}\right):$ e

Terrain character: of the backwall and the bridge seat. The upstream right wingwall has extensive

Stream character \& type: map cracking with leakage and efflorescence. The upstream left wingwall has a large spall at the

Streambed material: end. The downstream right

Discharge Data (cfs): $\quad \mathrm{Q}_{2.33} \frac{\text { wing- }}{\text { sists of }}$ $\mathrm{Q}_{50}$ sists of $\mathrm{Q}_{10} \frac{\text { wall }}{\mathrm{Q}_{100} \text { irregu- }}$ $Q_{25}$ con$Q_{500}$ lar

Record flood date $(M M / D D / Y Y)$ : lai / $\underline{\mathbf{d}} / \underline{\mathbf{u}}$ Water surface elevation (ft): $\underline{\mathbf{p}}$

Estimated Discharge (cfs): stone Velocity at $\mathrm{Q} \underline{\text { wit }}(\mathrm{ft} / \mathrm{s}): \underline{\mathbf{h} \text { a }}$ Ice conditions (Heavy, Moderate, Light): short sec- Debris (Heavy, Moderate, Light): tion of conThe stage increases to maximum highwater elevation (Rapidly, Not rapidly): crete. The The stream response is (Flashy, Not flashy): concrete has

Describe any significant site conditions upstream or downstream that may influence the stream's stage: fine map cracks and the laid up stone has voids and displacement. Both abutments have (continued page

Watershed storage area (in percent): $33 \%$

The watershed storage area is: _ _ (1-mainly at the headwaters; 2- uniformly distributed; 3-immediatly upstream oi the site)

Water Surface Elevation Estimates for Existing Structure:

\begin{tabular}{|l|l|l|l|l|l|}
\hline Peak discharge frequency & $\mathbf{Q}_{2.33}$ & $\mathrm{Q}_{10}$ & $\mathrm{Q}_{25}$ & $\mathrm{Q}_{50}$ & $\mathrm{Q}_{100}$ \\
Water surface elevation $(f t))$ & $\mathbf{N}$ & - & - & - & \\
Velocity $(f t / \mathrm{sec})$ & Gravel & , cob- & bles, & and & some \\
\hline
\end{tabular}

Long term stream bed changes: boulders

Is the roadway overtopped below the $Q_{100}$ ? (Yes, No, Unknown): __ _ Frequency: Relief Elevation $(f t)$ :

Discharge over roadway at $\mathrm{Q}_{100}\left(\mathrm{ft}^{3} / \mathrm{sec}\right)$ : -

Are there other structures nearby? (Yes, No, Unknown): If No or Unknown, type ctrl-n os Upstream distance (miles): Town: Year Built:

Highway No. : Structure No. : Structure Type:

Clear span (ft): Clear Height $(f t)$ : Full Waterway $\left(f^{2}\right)$ : 
Downstream distance (miles): Town:

Year Built:

Highway No. : Structure No. : Structure Type:

Clear span $(f t)$ : Clear Height (ft): Full Waterway $\left(f^{2}\right)$ :

Comments:

\section{USGS Watershed Data}

Watershed Hydrographic Data Drainage area (DA) $\frac{10.89}{\mathrm{mi}^{2}}$
Watershed storage $(S T) \quad \mathbf{0}$

Bridge site elevation $\mathbf{5 8 0} \mathrm{ft}$

Main channel length $\mathbf{7 . 0 5} \mathrm{mi}$

$10 \%$ channel length elevation $\mathbf{6 0 0}$

Lake/pond/swamp area $\mathrm{mi}^{2}$

Headwater elevation $\lcm{2510} \mathrm{ft}$ mi

Main channel slope $(S) \quad \mathbf{2 1 5 . 6} \mathrm{ft} / \mathrm{mi}$

Watershed Precipitation Data

Average site precipitation in Average headwater precipitation in

Maximum 2yr-24hr precipitation event $(124,2)$ in

Average seasonal snowfall (Sn) $\mathrm{ft}$ 


\section{Bridge Plan Data}

Are plans available? If no, type ctrl-n pl

Date issued for construction (MM / YYYY):

Project Number Minimum channel bed elevation:

Low superstructure elevation: USLAB DSLAB USRAB DSRAB Benchmark location description:

$\mathbf{U}$

$-$

$-$

Reference Point (MSL, Arbitrary, Other): $\mathbf{U}$

Datum (NAD27, NAD83, Other):

Foundation Type:

(1-Spreadfooting; 2-Pile; 3- Gravity; 4-Unknown)

If 1: Footing Thickness

Footing bottom elevation: -

If 2: Pile Type: (1-Wood; 2-Steel or metal; 3-Concrete)

Approximate pile driven length: -

If 3: Footing bottom elevation:

Is boring information available? If no, type ctrl-n bi Number of borings taken:

Foundation Material Type: (1-regolith, 2-bedrock, 3-unknown)

Briefly describe material at foundation bottom elevation or around piles:

$-$

$-$

$-$

$-$

$-$

$-$

Comments:

$-$

an exposed concrete footing. There is a small amount of stone fill in front of each footing. The channel bed is made up of gravel, cobbles, and some boulders. There is a small amount of scour just US from the bridge. There is some small tree debris and brush along the channel length. 


\section{Cross-sectional Data}

Is cross-sectional data available? If no, type ctrl-n xs

Source (FEMA, VTAOT, Other)? $\mathbf{N}$

Comments: -

\begin{tabular}{|l|l|l|l|l|l|l|l|l|l|l|l|}
\hline Station & - & NO & INF & & 4 & - & DRI & OR & & & Y \\
\hline Feature & - & BEN & OR & & - & N & LL & MA & & & VTA \\
\hline $\begin{array}{l}\text { Low chord } \\
\text { elevation }\end{array}$ & - & CK & MA & & - & - & BOR & TIO & & & OT \\
\hline $\begin{array}{l}\text { Bed } \\
\text { elevation }\end{array}$ & - & MA & TIO & - & - & 3 & ING & N & & & This \\
\hline $\begin{array}{l}\text { Low chord- } \\
\text { bed }\end{array}$ & - & RK & N & - & - & NO & INF & & - & & is a \\
\hline Station & cross & dow & low & from & done & $\mathbf{0 6 /}$ & cord & data & h & ge & date \\
\hline Feature & -sec- & nstre & cord & the & for & $\mathbf{1 2 /}$ & to & is & attac & inspe & d 11/ \\
\hline $\begin{array}{l}\text { Low chord } \\
\text { elevation }\end{array}$ & tion & am & ele- & sur- & this & $\mathbf{9 6 .}$ & bed & from & hed & ction & 04/ \\
\hline $\begin{array}{l}\text { Bed } \\
\text { elevation }\end{array}$ & of & face. & vatio & vey & repo & The & lengt & the & to a & repo & 93. \\
\hline $\begin{array}{l}\text { Low chord- } \\
\text { bed }\end{array}$ & the & The & n is & log & rt on & low & h & sketc & brid & rt & The \\
\hline
\end{tabular}

Source (FEMA, VTAOT, Other)? sketch

Comments: itself is dated $\mathbf{0 9 / 2 3 / 9 2}$.

o

\begin{tabular}{|l|l|l|l|l|l|l|l|l|l|l|l|}
\hline Station & RAB & - & - & - & LAB & - & - & - & - & - & - \\
\hline Feature & 496.1 & $\mathbf{4 9 6 . 0}$ & $\mathbf{4 9 6 . 0}$ & $\mathbf{4 9 5 . 9}$ & $\mathbf{4 9 5 . 8}$ & - & - & - & - & - & - \\
\hline $\begin{array}{l}\text { Low chord } \\
\text { elevation }\end{array}$ & $\mathbf{4 8 7 . 5}$ & $\mathbf{4 8 6 . 0}$ & $\mathbf{4 8 5 . 2}$ & $\mathbf{4 8 6 . 0}$ & $\mathbf{4 8 9 . 0}$ & - & - & - & - & - & - \\
\hline $\begin{array}{l}\text { Bed } \\
\text { elevation }\end{array}$ & $\mathbf{8 . 6}$ & $\mathbf{1 0}$ & $\mathbf{1 0 . 8}$ & $\mathbf{9 . 9}$ & $\mathbf{6 . 8}$ & - & - & - & - & - & - \\
\hline $\begin{array}{l}\text { Low chord- } \\
\text { bed }\end{array}$ & $\mathbf{5 . 5}$ & $\mathbf{1 0 . 2}$ & $\mathbf{1 5 . 6}$ & $\mathbf{2 1 . 6}$ & - & - & - & - & - & - & - \\
\hline Station & - & - & - & - & - & - & - & - & - & - & - \\
\hline Feature & - & - & - & - & - & - & - & - & - & - & - \\
\hline $\begin{array}{l}\text { Low chord } \\
\text { elevation }\end{array}$ & - & - & - & - & - & - & - & - & - & - & - \\
\hline $\begin{array}{l}\text { Bed } \\
\text { elevation }\end{array}$ & - & - & - & - & - & - & - & - & - & - & - \\
\hline $\begin{array}{l}\text { Low chord- } \\
\text { bed }\end{array}$ & - & - & - & - & - & - & - & - & - & - & - \\
\hline
\end{tabular}




\section{APPENDIX E: \\ LEVEL I DATA FORM}


U. S. Geological Survey

Bridge Field Data Collection and Processing Form

Qa/Qc Check by: MS Date: 6 /23/97

\section{Structure Number STARTH00250050}

Computerized by: $\mathbf{M S}$ Date: $6 / 24 / 97$

Reviewd by: $\quad \mathbf{R B}$ Date: 10/9/97

\section{A. General Location Descriptive}

1. Data collected by (First Initial, Full last name) E. BOEHMLER

2. Highway District Number $\mathbf{0 5}$

County 001 ADDISON

Waterway (I - 6) LEWIS CREEK

Route Number $\mathbf{C 3 0 2 5}$

3. Descriptive comments:

This bridge is located 0.3 miles from the junction with VT 116.
Mile marker 000000

Town 70075 STARKSBORO

Road Name TATRO RD

Hydrologic Unit Code: 2010002

\section{B. Bridge Deck Observations}
4. Surface cover... LBUS 4
RBUS 6
LBDS 4
RBDS 6
Overall 6

(2b us, ds,lb,rb: 1- Urban; 2- Suburban; 3- Row crops; 4- Pasture; 5- Shrub- and brushland; 6- Forest; 7- Wetland)
5. Ambient water surface... US 1
UB 1 DS $\underline{2}$
(1- pool; 2- riffle)

6. Bridge structure type 1 (1- single span; 2- multiple span; 3- single arch; 4- multiple arch; 5-cylindrical culvert; 6- box culvert; or 7- other)
7. Bridge length 28
(feet)
Span length 25
(feet)
Bridge width 14.6 (feet)

\section{Road approach to bridge:}
8. LB 2
RB 2
( 0 even, 1- lower, 2- higher)
9. LB
RB 2
(1- Paved, 2- Not paved)

10. Embankment slope (run / rise in feet / foot)

US left

US right

\begin{tabular}{|c|c|c|c|}
\hline \multicolumn{2}{|c|}{ Protection } & \multirow{2}{*}{ 13.Erosion } & 14.Severity \\
\hline 11.Type & 12.Cond. & $\underline{\mathbf{2}}$ & $\underline{\mathbf{1}}$ \\
\hline $\mathbf{1}$ & $\mathbf{1}$ & $\underline{\mathbf{2}}$ & $\underline{\mathbf{1}}$ \\
\hline $\mathbf{1}$ & $\mathbf{1}$ & $\underline{\mathbf{0}}$ & $\mathbf{0}$ \\
\hline $\mathbf{0}$ & - & $\underline{\mathbf{0}}$ & $\mathbf{1}$ \\
\hline $\mathbf{1}$ & $\mathbf{2}$ & $\underline{\mathbf{2}}$ & $\underline{\mathbf{1}}$ \\
\hline
\end{tabular}

Bank protection types: 0- none; 1- < 12 inches;

2- < 36 inches; 3- < 48 inches;

4- < 60 inches; 5- wall / artificial levee

Bank protection conditions: 1- good; 2- slumped;

3- eroded; 4- failed

Erosion: 0 - none; 1- channel erosion; 2-

road wash; 3- both; 4- other

Erosion Severity: 0 - none; 1- slight; 2- moderate; 3- severe

Channel approach to bridge (BF):

15. Angle of approach: $\mathbf{0}$

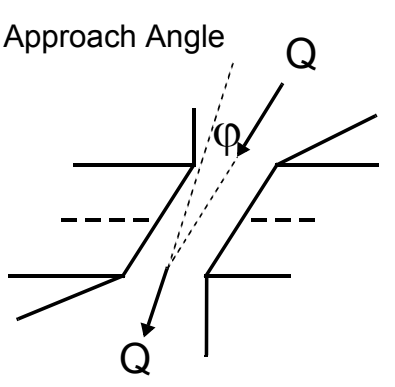

17. Channel impact zone 1 :

Where? RB $(L B, R B)$

Range? 24 feet $\underline{\text { US }}$

Channel impact zone 2:

Where? LB $(L B, R B)$

Range? $\underline{55}$ feet $\underline{\mathbf{D S}}$ (US, UB, DS) to $\underline{90}$ feet $\underline{\mathbf{D S}}$

Impact Severity: 0- none to very slight; 1- Slight; 2- Moderate; 3- Severe
16. Bridge skew: $\mathbf{0}$ Bridge Skew Angle

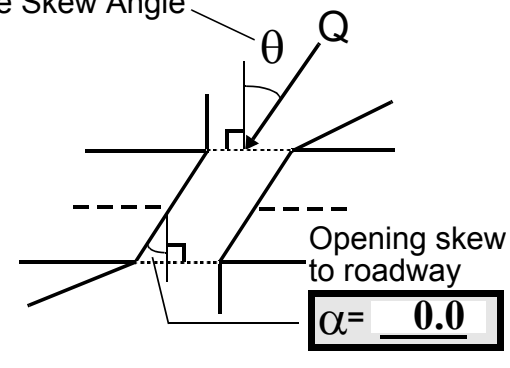

\section{Exist? $\mathbf{Y}(Y$ or $N)$}

(US, UB, DS) to $\underline{\mathbf{5 0}}$ feet $\underline{\mathbf{U S}}$

Exist? $\mathbf{Y}(\mathrm{Y}$ or $N)$

Severity 2
Severity 11 
18. Bridge Type: 1a

1a- Vertical abutments with wingwalls

$1 \mathrm{~b}$ - Vertical abutments without wingwalls

2- Vertical abutments and wingwalls, sloping embankment Wingwalls parallel to abut. face

3- Spill through abutments

4- Sloping embankment, vertical wingwalls and abutments

Wingwall angle less than $90^{\circ}$.

19. Bridge Deck Comments (surface cover variations, measured bridge and span lengths, bridge type variations,

approach overflow width, etc.)

4. The surface cover is as indicated on the previous page. The only variation is on the US left bank where there is a barn and house a considerable distance from the channel.

7. The measured values for the bridge length, span length, and the bridge width are $28 \mathrm{ft}, 26 \mathrm{ft}$, and $14.7 \mathrm{ft}$ respectively.

18. The wingwalls are only $4 \mathrm{ft}$ high. There is no DS left wingwall.

\section{Upstream Channel Assessment}

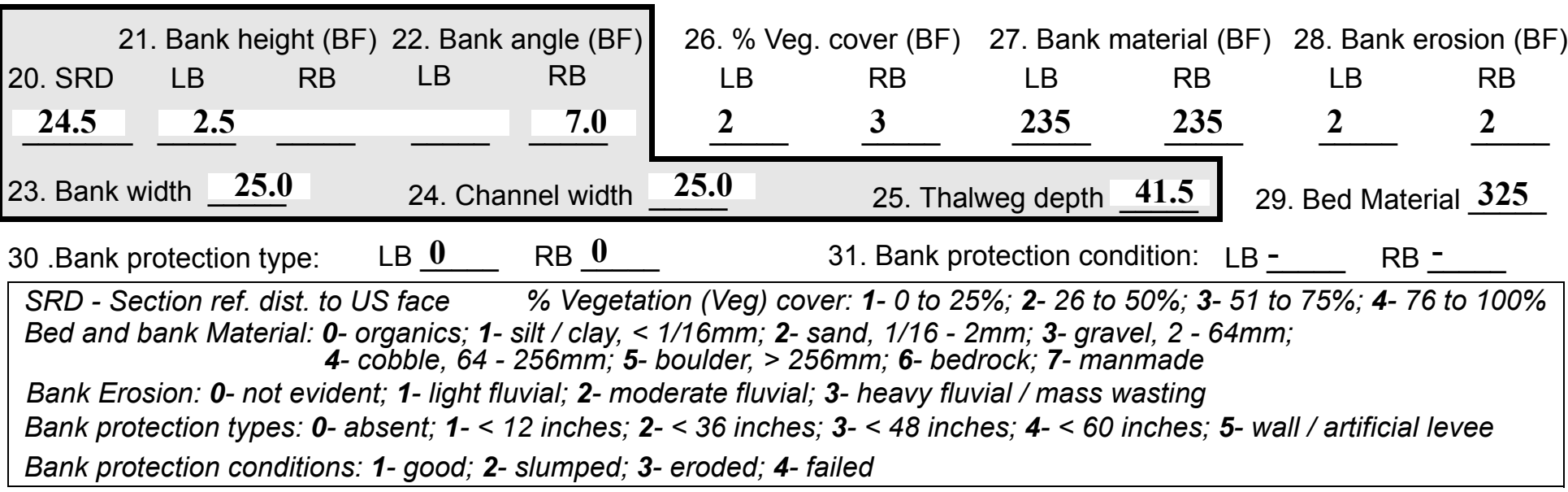

32. Comments (bank material variation, minor inflows, protection extent, etc.):

The US reach to the bridge is moderately steep. There is a slight bend in the channel causing the flow to impact the right bank. The right bank and left bank are slightly scalloped. The flow is eroding the bank material from between the boulders and trees on the bank line. 
33.Point/Side bar present? $\mathbf{N}(Y$ or $N$. if $N$ type ctrl-n pb)34. Mid-bar distance: -

35. Mid-bar width: -

36. Point bar extent: feet (US, UB) to feet (US, UB, DS) positioned $\%$ LB to $\% \mathrm{RB}$

37. Material:

38. Point or side bar comments (Circle Point or Side; Note additional bars, material variation, status, etc.):

NO POINT BARS

39. Is a cut-bank present? $\underline{\mathbf{Y}}(\mathrm{Y}$ or if $N$ type $c t r-n c b)$ 40. Where? $\underline{\mathbf{R B}}$ (LB or RB)

41. Mid-bank distance: $\mathbf{7 0}$

42. Cut bank extent: $\mathbf{5 0}$ (US, UB) to $\underline{\mathbf{1 2 5}}$ feet $\underline{\mathbf{U S}}$ (US, UB, DS)

43. Bank damage: 1 (1- eroded and/or creep; 2- slip failure; 3- block failure)

44. Cut bank comments (eg. additional cut banks, protection condition, etc.):

The cut bank features a downed tree in the stream and other trees with heavy root exposure. The bank material is also being slightly undermined in places.

\section{Is channel scour present? $\mathbf{Y}$ ( $Y$ or if $N$ type ctrl-n cs)}

46. Mid-scour distance: 0

47. Scour dimensions: Length 43 Width 5 Depth : 1

Position 60 $\%$ LB to 90

48. Scour comments (eg. additional scour areas, local scouring process, etc.):

This scour hole extends under the bridge from $16 \mathrm{ft}$ US to $12 \mathrm{ft}$ DS.

\section{Are there major confluences? $\mathbf{N}$}

51. Confluence 1: Distance Confluence 2: Distance 52. Enters on Enters on 4. Confluence comments (eg. confluence name):

NO MAJOR CONFLUENCES
50. How many? -

53. Type(1- perennial; 2- ephemeral)

Type (1-perennial; 2- ephemeral)

NO MAJOR CONFLUENCE

\section{Under Bridge Channel Assessment}

55. Channel restraint (BF)? LB 2

\begin{tabular}{|ccccc}
\hline \multicolumn{2}{|c}{ 56. Height (BF) } & \multicolumn{3}{c}{57 Angle (BF) } \\
LB & RB & LB & RB \\
$\mathbf{2 3 . 0}$ & & & $\mathbf{1 . 5}$ & \\
\hline
\end{tabular}

58. Bank width (BF) (1- natural bank; 2- abutment; 3- artificial levee)

Bed and bank Material: 0- organics; 1- silt / clay, < 1/16mm; 2- sand, 1/16 - 2mm; 3- gravel, 2 - 64mm; 4- cobble, 64 - 256mm; 5- boulder, > 256mm; 6- bedrock; 7- manmade

\begin{tabular}{lclc} 
61. Material (BF) & \multicolumn{3}{l}{ 62. Erosion (BF) } \\
LB & RB & LB & RB \\
$\mathbf{2}$ & $\mathbf{7}$ & & $\mathbf{7}$ \\
\hline
\end{tabular}

60. Thalweg depth $\lcm{90.0}$

63. Bed Material -

Bank Erosion: 0- not evident; 1- light fluvial; 2- moderate fluvial; 3- heavy fluvial / mass wasting

64. Comments (bank material variation, minor inflows, protection extent, etc.):

325

The channel narrows through the bridge by approximately $10 \%$ of its width at the approach section. The channel under the bridge is $1 \mathrm{ft}$. deeper than US and DS. 
65. Debris and Ice Is there debris accumulation?

(Yor $N)$ 66. Where? $\underline{Y}$

(1- Upstream; 2- At bridge; 3- Both)

67. Debris Potential 1 (1-Low; 2- Moderate; 3- High)

68. Capture Efficiency 2

(1-Low; 2- Moderate; 3- High)

69. Is there evidence of ice build-up? 2 (Y or $N)$

Ice Blockage Potential $\underline{Y}$

(1-Low; 2- Moderate; 3- High)

70. Debris and Ice Comments:

2

Debris US is caught in the trees along the bank. Some of the trees are leaning in toward the channel, especially at the cut bank. There is some ice scarring of trees located on the US right bank.

\begin{tabular}{|l|c|c|c|c|c|c|c|c|}
\hline Abutments & $\begin{array}{c}\text { 71. Attack } \\
\angle \text { (BF) }\end{array}$ & $\begin{array}{c}72 \text {. Slope } \angle \\
\text { (Qmax) }\end{array}$ & $\begin{array}{c}\text { 73. Toe } \\
\text { loc. (BF) }\end{array}$ & $\begin{array}{c}\text { 74. Scour } \\
\text { Condition }\end{array}$ & $\begin{array}{c}75 . \text { Scour } \\
\text { depth }\end{array}$ & $\begin{array}{c}\text { 76. Exposure } \\
\text { depth }\end{array}$ & 77. Material & 78. Length \\
\hline LABUT & & $\mathbf{0}$ & $\mathbf{9 0}$ & $\mathbf{2}$ & $\mathbf{2}$ & $\mathbf{0}$ & $\mathbf{2}$ & $\mathbf{9 0 . 0}$ \\
\hline RABUT & $\mathbf{1}$ & $\mathbf{5}$ & $\mathbf{9 0}$ & & & $\mathbf{2}$ & $\mathbf{2}$ & $\mathbf{2 3 . 5}$ \\
\hline
\end{tabular}

Pushed: $L B$ or RB

Toe Location (Loc.): 0- even, 1- set back, 2- protrudes

Scour cond.: 0- not evident; 1- evident (comment); 2- footing exposed; 3-undermined footing; 4- piling exposed; 5- settled; 6- failed

Materials: 1- Concrete; 2- Stone masonry or drywall; 3- steel or metal; 4- wood

79. Abutment comments (eg. undermined penetration, unusual scour processes, debris, etc.):

0

1

1

The left abutment footing exposure ranges from $2 \mathrm{ft}$ to $2.5 \mathrm{ft}$. The right abutment footing exposure ranges from 0.5 ft to $1.5 \mathrm{ft}$.

80. Wingwalls:

Exist? Material? Scour Scour Exposure $\begin{aligned} & 81 . \\ & \text { Angle? Length? }\end{aligned}$ Condition? depth? depth?

USLWW:

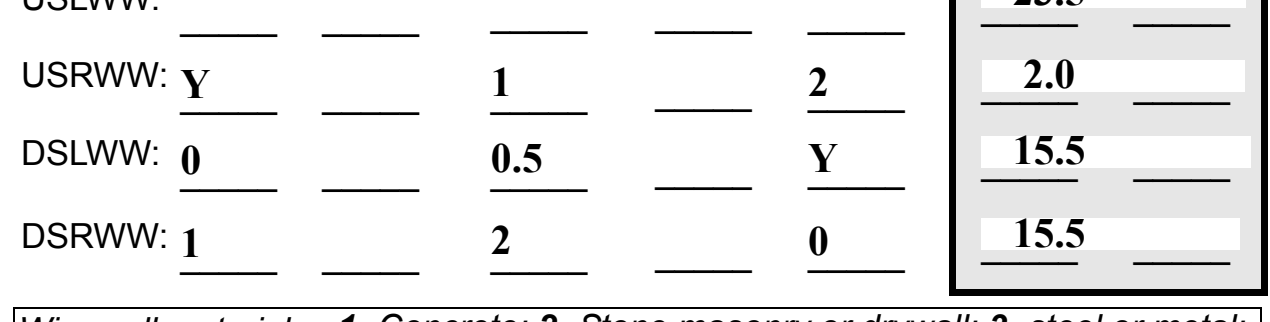

Wingwall materials: 1- Concrete; 2- Stone masonry or drywall; 3- steel or metal; 4- wood

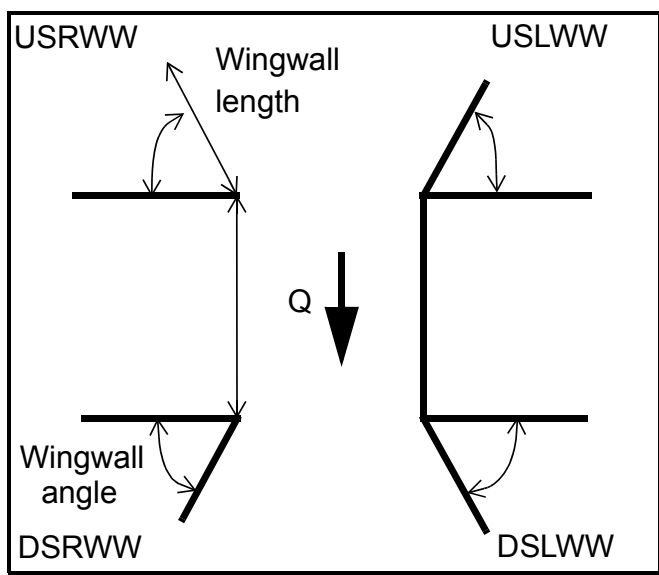

82. Bank / Bridge Protection:

\begin{tabular}{|l|l|l|l|l|l|l|l|c|}
\hline Location & USLWW & USRWW & LABUT & RABUT & LB & RB & DSLWW & DSRWW \\
\hline Type & $\mathbf{0 . 5}$ & - & $\mathbf{Y}$ & $\mathbf{0}$ & - & $\mathbf{1}$ & $\mathbf{2}$ & $\mathbf{1}$ \\
\hline Condition & $\mathbf{N}$ & - & $\mathbf{1}$ & $\mathbf{1}$ & - & $\mathbf{1}$ & $\mathbf{1}$ & $\mathbf{1}$ \\
\hline Extent & - & - & $\mathbf{2}$ & $\mathbf{0}$ & $\mathbf{2}$ & $\mathbf{1}$ & $\mathbf{2}$ & - \\
\hline
\end{tabular}

Bank / Bridge protection types: 0- absent; 1-<12 inches; 2- < 36 inches; 3- < 48 inches; 4- < 60 inches; 
83. Wingwall and protection comments (eg. undermined penetration, unusual scour processes, etc.):

-
-
-
-
-
-
-
2
1
1

\section{Piers:}

84. Are there piers? Th (Y or if $N$ type ctrl-n pr)

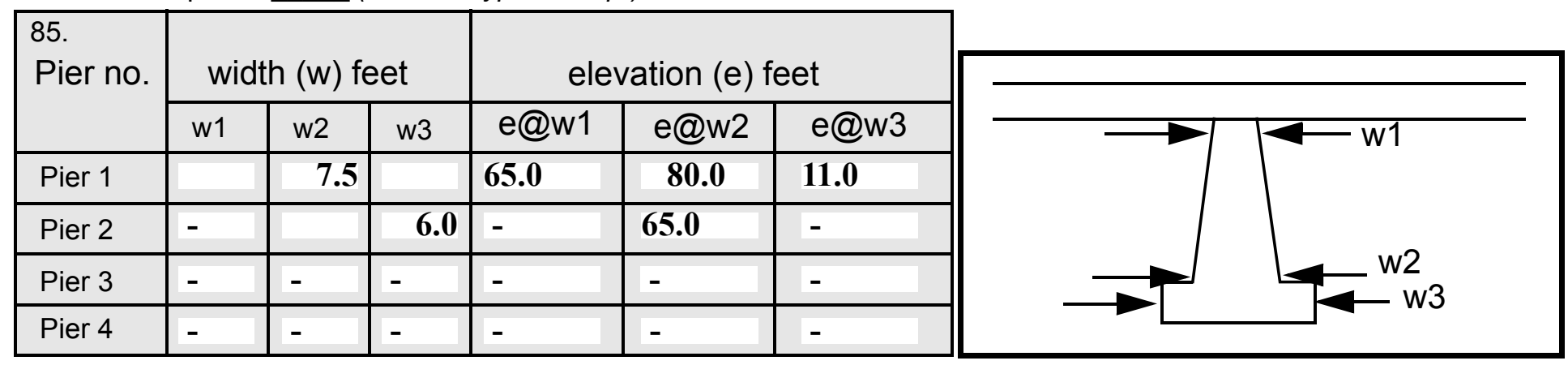

\begin{tabular}{|l|l|l|l|l|}
\hline Level 1 Pier Descr. & \multicolumn{1}{|c|}{1} & \multicolumn{1}{|c|}{2} & \multicolumn{1}{|c|}{3} & \multicolumn{1}{|c|}{} \\
\hline 86. Location (BF) & e US & to 1 ft. & from 1 & ranges \\
\hline 87. Type & right & The & ft to & from \\
\hline 88. Material & wing & US & $\mathbf{2}$ ft. & $\mathbf{0 . 5} \mathbf{f t}$ \\
\hline 89. Shape & wall & left & The & to 1 \\
\hline 90. Inclined? & foot- & wing & DS & ft. \\
\hline 91. Attack $\angle$ (BF) & ing & wall & right & \\
\hline 92. Pushed & expo & foot- & wing & \\
\hline 93. Length (feet) & - & - & - & - \\
\hline 94. \# of piles & sure & ing & wall & \\
\hline 95. Cross-members & rang & expo & foot- & \\
\hline 96. Scour Condition & es & sure & ing & \\
\hline 97. Scour depth & from & rang & expo & \\
\hline 98. Exposure depth & 0 ft & es & sure & \\
\hline
\end{tabular}

LFP, LTB, LB, MCL, MCM, MCR, RB, RTB, RFP

1- Solid pier, 2- column, 3- bent

1-Wood; 2- concrete; 3- metal; 4- stone

1- Round; 2- Square; 3- Pointed

Y-yes; $N-$ no

$L B$ or $R B$

0- none; 1- laterals; 2- diagonals; 3- both

0- not evident; 1- evident (comment);

2- footing exposed; 3- piling exposed;

4- undermined footing; 5- settled; 6- failed 
99. Pier comments (eg. undermined penetration, protection and protection extent, unusual scour processes, etc.):

$\mathbf{N}$

$-$

$-$

$-$

$-$

100.

\section{E. Downstream Channel Assessment}

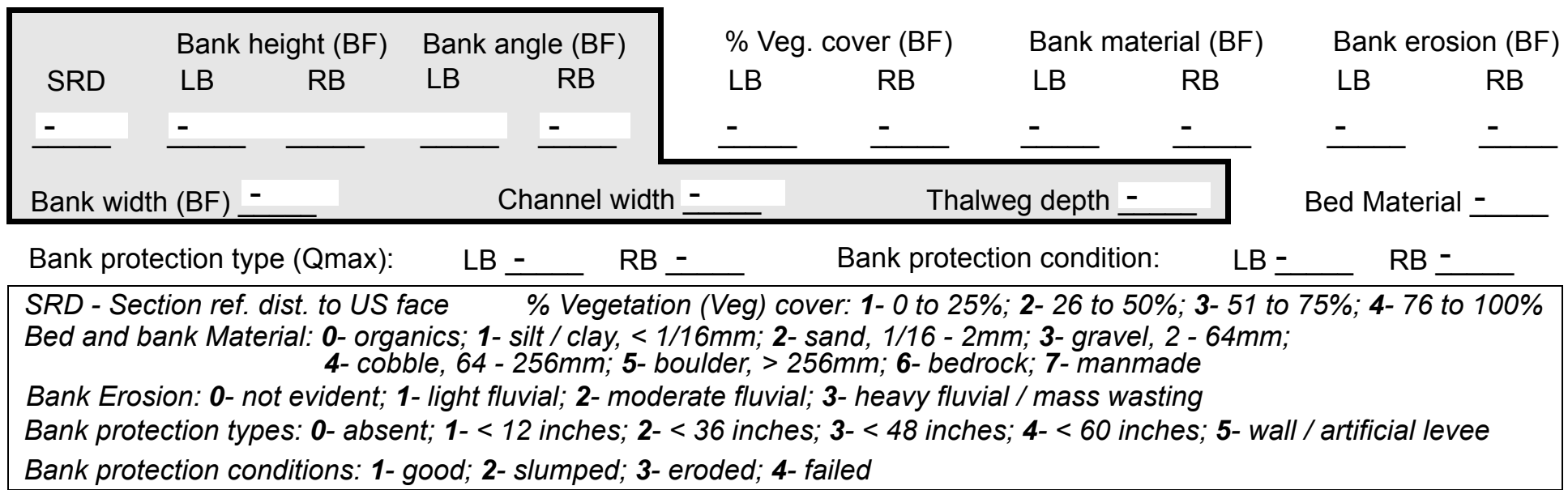

Comments (eg. bank material variation, minor inflows, protection extent, etc.):$$
-
$$

$-$

$-$

$-$

-

$-$

$-$

$-$

$-$

-

$-$

$-$

$-$

$-$

$-$

\section{Is a drop structure present? __ ( $Y$ or $N$, if $N$ type ctrl-n $d s) \quad$ 102. Distance: ___ feet}

103. Drop: __ feet 104. Structure material: __ (1- steel sheet pile; 2- wood pile; 3- concrete; 4- other)

105. Drop structure comments (eg. downstream scour depth):

$-$

$-$

$-$

$-$

-

- 
106. Point/Side bar present? (Y or $N$. if $N$ type ctrl-n pb)Mid-bar distance: Mid-bar width: -

Point bar extent: feet (US, UB, DS) to feet (US, UB, DS) positioned $\underline{\mathbf{N O}}$ \%LB to $\underline{\text { PI }} \%$ RB Material: $\underline{\mathbf{E R}}$

Point or side bar comments (Circle Point or Side; note additional bars, material variation, status, etc.): $\mathbf{S}$

Is a cut-bank present? (Y or if $N$ type ctrl-n cb) Where? (LB or $R B)$ Mid-bank distance:

Cut bank extent: feet (US, UB, DS) to feet 1 (US, UB, DS)

Bank damage: $\mathbf{3}$ (1- eroded and/or creep; 2- slip failure; 3- block failure)

Cut bank comments (eg. additional cut banks, protection condition, etc.):

235

235

2

1

Is channel scour present? 325 (Y or if $N$ type ctrl-n cs) Mid-scour distance: $\underline{\mathbf{0}}$ Scour dimensions: Length 0 _ Width _ _ Depth: - _ Positioned ___ \%LB to __ \%RB Scour comments (eg. additional scour areas, local scouring process, etc.):

Are there major confluences? ( $Y$ or if $N$ type ctrl-n $m c)$

How many?

Confluence 1: Distance Enters on (LB or $R B)$

Type (1- perennial; 2- ephemeral)

Confluence 2: Distance

Enters on (LB or $R B)$

Type (1- perennial; 2- ephemeral)

Confluence comments (eg. confluence name):

$\mathbf{N}$

\section{F. Geomorphic Channel Assessment}

107. Stage of reach evolution -

1- Constructed

2- Stable

3- Aggraded

4- Degraded

5- Laterally unstable

6- Vertically and laterally unstable 
108. Evolution comments (Channel evolution not considering bridge effects; See HEC-20, Figure 1 for geomorphic descriptors):

NO DROP STRUCTURE

$\mathbf{N}$

$-$

$-$

$-$

$-$

$-$

$-$ 


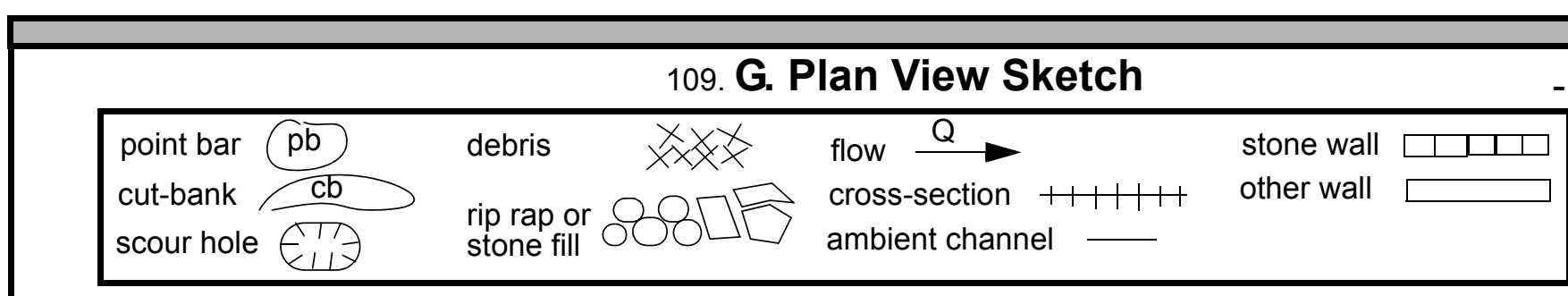


APPENDIX F:

SCOUR COMPUTATIONS 


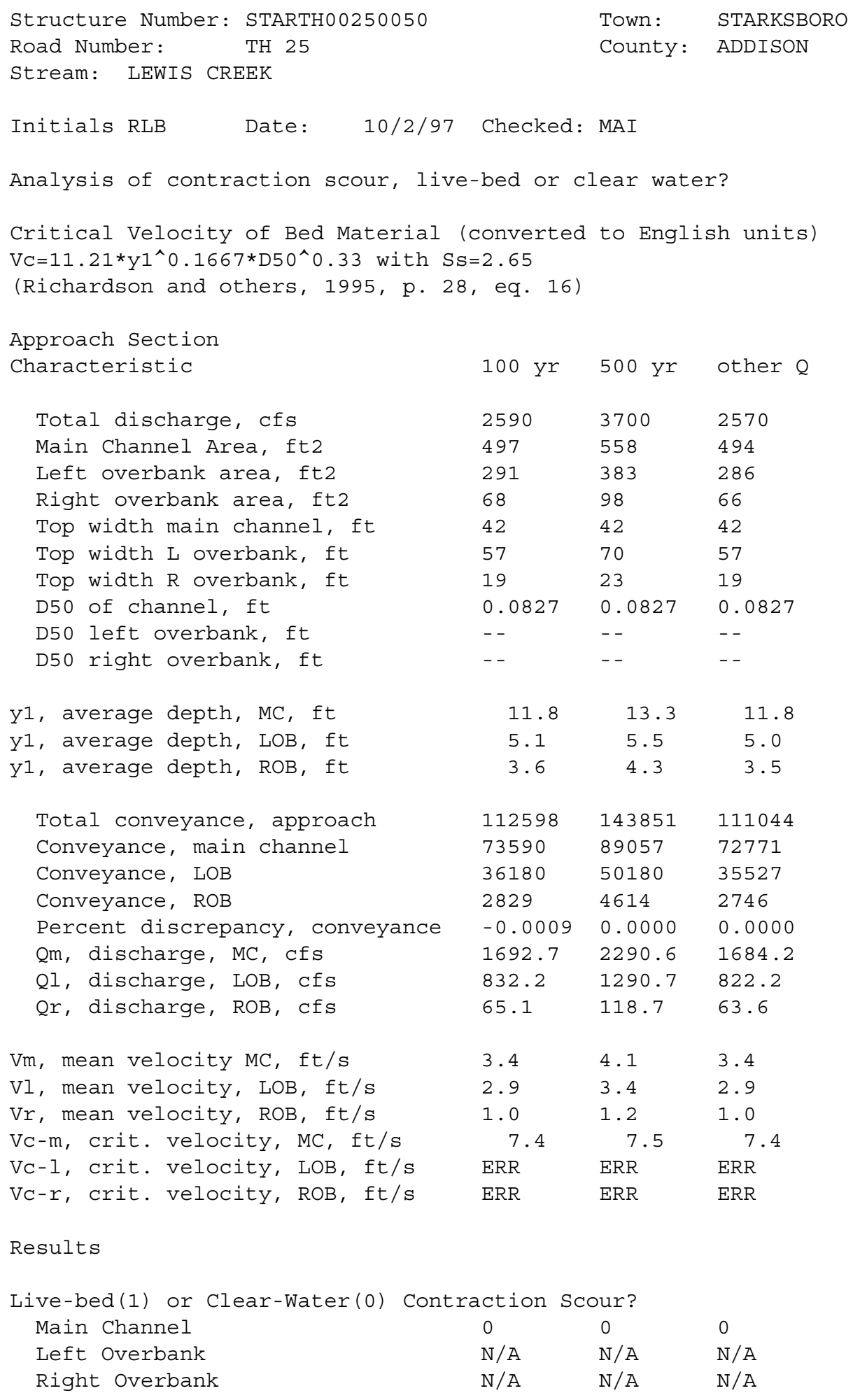


Clear water Contraction Scour in MAIN CHANNEL

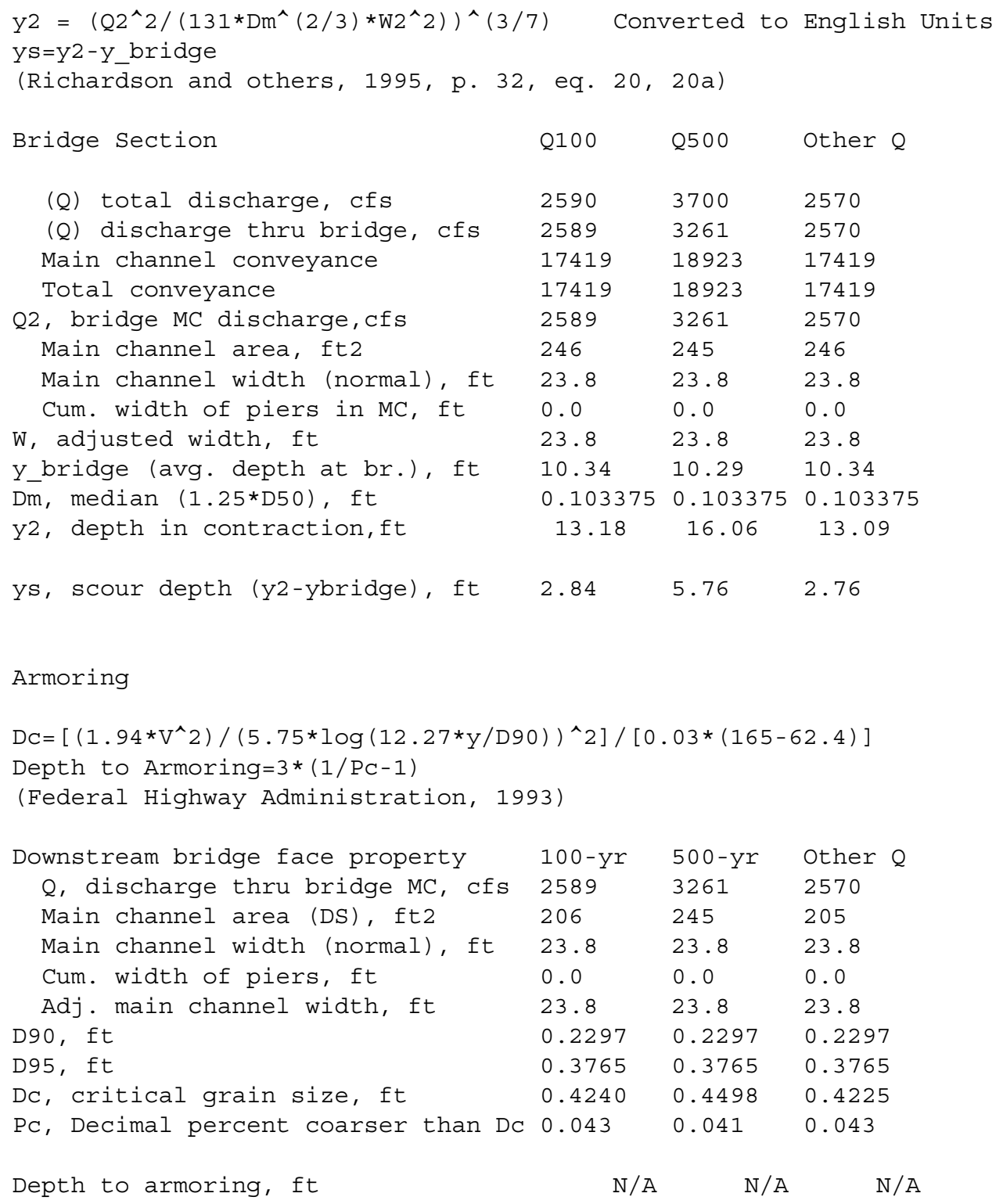




\begin{tabular}{|c|c|c|c|}
\hline \multicolumn{4}{|c|}{$\begin{array}{l}\text { Umbrell pressure flow equation } \\
(\mathrm{Hb}+\mathrm{Ys}) / \mathrm{ya}=1.1021 *[(1-\mathrm{w} / \mathrm{ya}) *(\mathrm{Va} / \mathrm{VC})] \wedge 0.6031 \\
\text { (Richardson and other, 1995, p. 144-146) }\end{array}$} \\
\hline & Q100 & Q500 & OtherQ \\
\hline Q, total, cfs & 2590 & 3700 & 2570 \\
\hline Q, thru bridge $\mathrm{MC}$, cfs & 2589 & 3261 & 2570 \\
\hline Vc, critical velocity, ft/s & 7.37 & 7.52 & 7.37 \\
\hline Va, velocity MC approach, ft/s & 3.41 & 4.11 & 3.41 \\
\hline Main channel width (normal), ft & 23.8 & 23.8 & 23.8 \\
\hline Cum. width of piers in MC, ft & 0.0 & 0.0 & 0.0 \\
\hline W, adjusted width, ft & 23.8 & 23.8 & 23.8 \\
\hline qbr, unit discharge, ft2/s & 108.8 & 137.0 & 108.0 \\
\hline Area of full opening, ft2 & 246.0 & 245.0 & 246.0 \\
\hline Hb, depth of full opening, ft & 10.34 & 10.29 & 10.34 \\
\hline Fr, Froude number, bridge MC & 0.58 & 0.73 & 0.57 \\
\hline Cf, Fr correction factor $(<=1.0)$ & 1.00 & 1.00 & 1.00 \\
\hline **Area at downstream face, ft2 & 206 & $\mathrm{~N} / \mathrm{A}$ & 205 \\
\hline **Hb, depth at downstream face, ft & 8.66 & $\mathrm{~N} / \mathrm{A}$ & 8.61 \\
\hline **Fr, Froude number at DS face & 0.75 & $E R R$ & 0.75 \\
\hline **Cf, for downstream face $(<=1.0)$ & 1.00 & $\mathrm{~N} / \mathrm{A}$ & 1.00 \\
\hline Elevation of Low Steel, ft & 495.95 & 495.95 & 495.95 \\
\hline Elevation of Bed, ft & 485.61 & 485.66 & 485.61 \\
\hline Elevation of Approach, ft & 498.67 & 500.12 & 498.59 \\
\hline Friction loss, approach, ft & 0.05 & 0.07 & 0.05 \\
\hline Elevation of WS immediately US, ft & 498.62 & 500.05 & 498.54 \\
\hline ya, depth immediately US, ft & 13.01 & 14.39 & 12.93 \\
\hline Mean elevation of deck, ft & 498.72 & 498.72 & 498.72 \\
\hline$w$, depth of overflow, ft $(>=0)$ & 0.00 & 1.33 & 0.00 \\
\hline Cc, vert contrac correction $(<=1.0)$ & 0.94 & 0.94 & 0.94 \\
\hline$* * \mathrm{CC}$, for downstream face $(<=1.0)$ & 0.892709 & ERR & 0.89313 \\
\hline Ys, scour w/Chang equation, ft & 5.31 & 9.08 & 5.18 \\
\hline Ys, scour w/Umbrell equation, ft & -1.34 & 0.10 & -1.38 \\
\hline
\end{tabular}




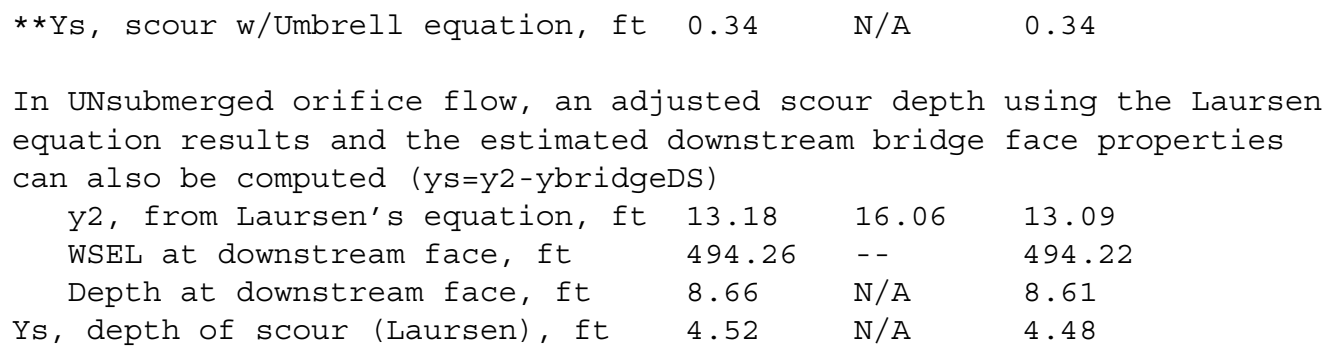

Abutment Scour

Froehlich's Abutment Scour

$\mathrm{Ys} / \mathrm{Y} 1=2.27 * \mathrm{~K} 1 * \mathrm{~K} 2 *\left(\mathrm{a}^{\prime} / \mathrm{Y} 1\right)^{\wedge} 0.43 * \mathrm{Fr} 1^{\wedge} 0.61+1$

(Richardson and others, 1995, p. 48, eq. 28)

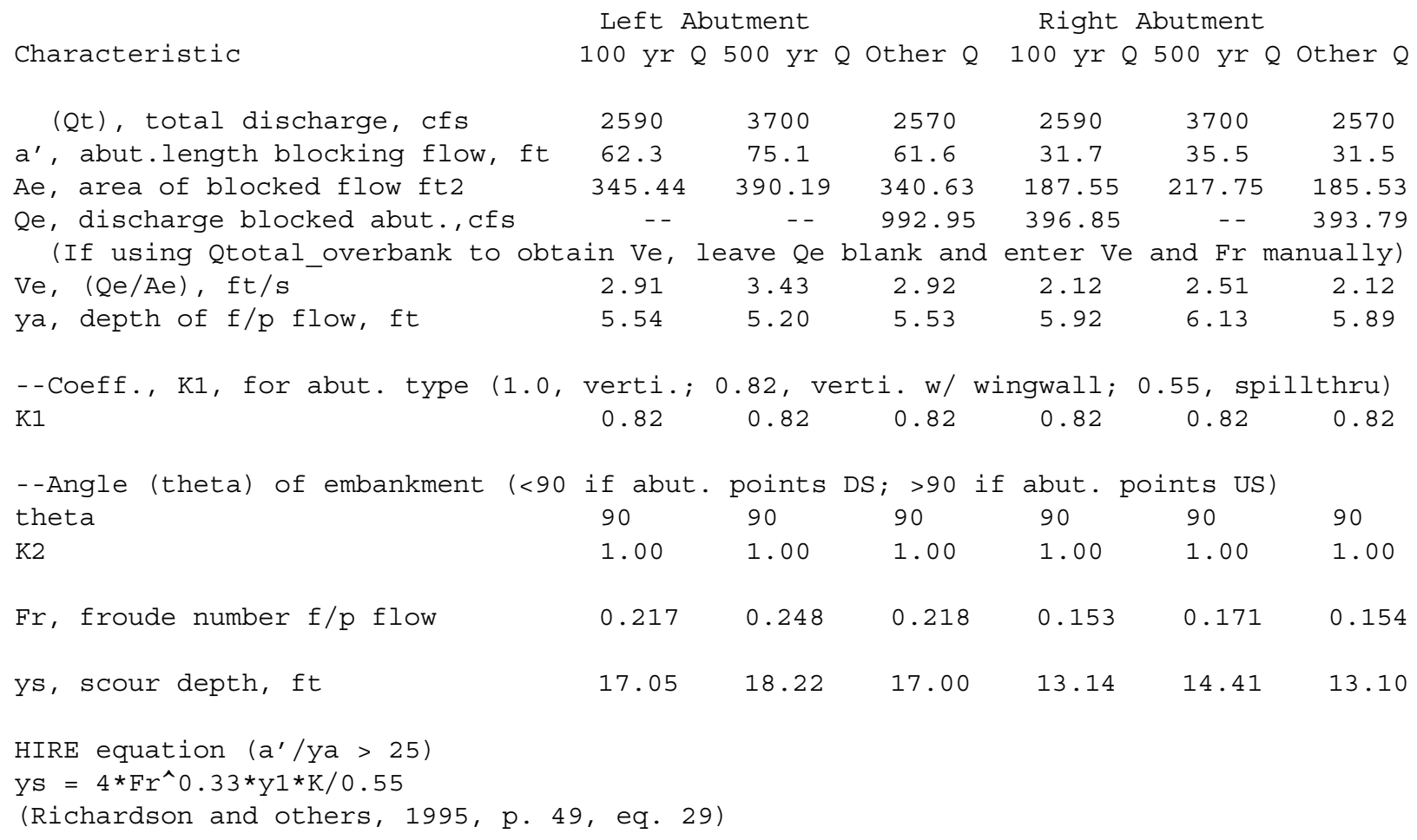




\begin{tabular}{|c|c|c|c|c|c|c|}
\hline a' (abut length blocked, ft) & 62.3 & 75.1 & 61.6 & 31.7 & 35.5 & 31.5 \\
\hline y1 (depth f/p flow, ft) & 5.54 & 5.20 & 5.53 & 5.92 & 6.13 & 5.89 \\
\hline$a^{\prime} / y 1$ & 11.24 & 14.45 & 11.14 & 5.36 & 5.79 & 5.35 \\
\hline Skew correction (p. 49, fig. 16) & 1.00 & 1.00 & 1.00 & 1.00 & 1.00 & 1.00 \\
\hline Froude no. f/p flow & 0.22 & 0.25 & 0.22 & 0.15 & 0.17 & 0.15 \\
\hline Ys w/ corr. factor $\mathrm{K} 1 / 0.55$ : & FRR & ERR & & & & \\
\hline vertical w/ ww's & $\begin{array}{l}\text { ERR } \\
\mathrm{ERR}\end{array}$ & $\begin{array}{l}\mathrm{ERR} \\
\mathrm{ERR}\end{array}$ & $\begin{array}{l}\text { ERR } \\
\text { ERR }\end{array}$ & $\begin{array}{l}\text { ERR } \\
\text { ERR }\end{array}$ & $\begin{array}{l}\text { ERR } \\
\text { ERR }\end{array}$ & $\begin{array}{l}\text { ERR } \\
\text { ERR }\end{array}$ \\
\hline spill-through & ERR & ERR & ERR & ERR & ERR & ERR \\
\hline Abutment riprap Sizing & & & & & & \\
\hline Isbash Relationship & & & & & & \\
\hline $\begin{array}{l}\mathrm{D} 50=\mathrm{Y} * \mathrm{~K} * \mathrm{Fr}{ }^{\wedge} 2 /(\mathrm{Ss}-1) \text { and } \mathrm{D} 50=\mathrm{Y} * \mathrm{~K} *( \\
\text { (Richardson and others, 1995, p11 }\end{array}$ & $\begin{array}{l}\wedge \\
\text { eq })^{\wedge} 0\end{array}$ & (S) & & & & \\
\hline Characteristic & Q100 & Q500 & Other Q & Q100 & Q500 & Other Q \\
\hline Fr, Froude Number & 0.75 & 0.73 & 0.75 & 0.75 & 0.73 & 0.75 \\
\hline y, depth of flow in bridge, ft & 8.66 & 10.29 & 8.61 & 8.66 & 10.29 & 8.61 \\
\hline Median Stone Diameter for riprap & $\therefore$ left & utment & & right & abutment, & ft \\
\hline Fr<=0.8 (vertical abut.) & 3.01 & 3.39 & 2.99 & 3.01 & 3.39 & 2.99 \\
\hline Fr>0.8 (vertical abut.) & ERR & $\mathrm{ERR}$ & ERR & ERR & ERR & ERR \\
\hline
\end{tabular}

